\title{
The Information Act: A Preliminary Analysis
}

\author{
Kenneth Culp Davis
}

The Information Act, ${ }^{1}$ effective July 4, 1967, requires disclosure of government records to "any person" except as "specifically stated" in the nine exemptions or in other provisions. District courts are given jurisdictions to enjoin an agency from withholding records.

The Act is difficult to interpret, and in some respects it is badly drafted. For instance, even though no reasonable person could have intended such a result, the Act in clear terms requires disclosure of non-commercial and non-financial information furnished to the government with a good faith understanding that it will be kept confidential. ${ }^{2}$ Many problems of applying the Act can be solved only by going outside the Act, as by resort to the idea that an equity court will refuse to enforce what is plainly contrary to the traditions of equity practice, or by resort to the constitutional doctrine of executive privilege.

The Attorney General in June, 1967, released a 47-page printed pamphlet entitled Attorney General's Memorandum on the Public Information Section of the Administrative Procedure $A c t,{ }^{3}$ skilfully analyzing the Act sentence by sentence. The Memorandum is the law in the sense that it guides the government's practices under the Act, but it is not the law in the sense of binding the courts. Its quality is excellent but, quite legitimately, it reflects the point of view of the agencies, all of whom opposed the enactment. It is usually persuasive, but not always, as we shall see.

No one can now foresee the ultimate solutions of the many perplexing problems of interpretation. Yet practitioners and others are immediately confronted with these problems. An independent analysis, even though preliminary, may therefore be helpful at this stage.

Kenneth Culp Davis is the John P. Wilson Professor of Law, University of Chicago Law School. For reading the manuscript and making valuable suggestions, the author thanks Professor Frank Newman of the University of California (Berkeley), and his two colleagues at the University of Chicago, Professors Philip Kurland and Walter Blum.

180 Stat. 250 (1966), codified by 81 Stat. 54 (1967), 5 U.S.C. $\S 552$.

2 See discussion in $\$ 19$ infra.

3 Hereinafter cited as ATT'Y GEN. MEMo. 


\section{A Quick Perspective}

The full texts of the original Act and of the codified Act ${ }^{4}$ are set forth as an appendix to this article. The entire Act is the new section 3 of the Administrative Procedure Act. The first clause says: "Every agency shall make available to the public the following information." The first four subsections contain the affirmative provisions. Subsection (a) governs publication in the Federal Register. Subsection (b) governs disclosure of six kinds of documents-opinions, orders, statements of policy, interpretations, staff manuals, and instructions. Subsection (c) provides that "every agency shall, upon request for identifiable records ... make such records promptly available to any person." Subsection (d) requires disclosure of final votes of each member of an agency in every proceeding. But subsection (e), containing nine exemptions, takes back a goodly portion of what the first four subsections give. The meaning of the exemptions is vitally affected by subsection (f), which says: "Nothing in this section [the entire Information Act] authorizes withholding of information or limiting the availability of records to the public except as specifically stated in this section ..."Because the extent of required disclosure usually depends upon interpretation of the exemptions, this "specifically stated" clause usually aggravates the difficulties of interpretation. Indeed, one recurring problem is what to do when no exemption "specifically" authorizes nondisclosure but when common sense obviously requires it. ${ }^{5}$

\section{The Legislative History in General}

Even though the records of the various hearings over a ten year period are voluminous, probably more than ninety-five per cent of the useful legislative history is found in a ten page Senate committee report and in a fourteen page House committee report. ${ }^{6}$ Problems of interpretation

4 This article necessarily uses the language of the 1966 enactment, for the legislative history, which is often crucial, is geared to that. The codification became effective June 5,1967 . Of course, the theory of the codification is that the substance is unchanged.

5 Subsection (g) defines "private party," and subsection (h) specifies the time the Act becomes effective.

6 S. REP. No. 813, 89th Cong., Ist Sess. (1965) [hereinafter cited as SEN. REP.]; H.R. REP. No. 1497, 89th Cong., 2d Sess. [hereinafter cited as House Rep.]. See also S. REP. No. 1219, 88th Cong., 2d Sess. (1964); Hearings before the Subcommittee on Administrative Practice and Procedure of the Senate Judiciary Committee on S. 1160, S. 1336, S. 1758, and S. 1879, Administrative Procedure Act, 89th Cong., 1st Sess. (1965); Hearings Before the Subcommittee of the House Committee on Government Operations, on H.R. 5012-21, 5237, 5406, 5520, 5583, 6172, 6739, 7010, and 7161, Federal Public Records Law, 89th Cong., 1st Sess. (1965); Hearings before the Subcommittee on Administrative Practice and Procedure of the Senate Judiciary Committee on S. 1663, Administrative Procedure Act, 88th Cong., 2d Sess. (1964); Hearings before the Subcommittee of the House Committee on Government Operations, Government Information, Plans and Policies, 88th Cong., 1st Sess. 
are aggravated not only by the "specifically stated" clause but also by the differences between what the Act says on its face and what the committee reports say, and they are further complicated by differences between the two committee reports. In general, the Senate committee is relatively faithful to the words of the Act, and the House committee ambitiously undertakes to change the meaning that appears in the Act's words. The main thrust of the House committee remarks that seem to pull away from the literal statutory words is almost always in the direction of nondisclosure. The Attorney General's Memorandum consistently relies on such remarks by the House committee.

\section{Executive Privilege}

A vital part of the background of the Act is the doctrine of executive privilege, under which nearly every President, beginning with Washington, has asserted constitutional power to withhold records. The Presidents have often withheld information from Congress and have always prevailed in doing so except when they have voluntarily yielded, although no such case has been judicially determined. A clear statement of the modern doctrine was made by President Eisenhower on May 17, 1954: "[T]hroughout our history the President has withheld information whenever he found that what was sought was confidential or its disclosure would be incompatible with the public interest or jeopardize the safety of the Nation."7 A 1957 study by the Department of Justice claimed even more executive power. ${ }^{8}$

Some of the literature about executive privilege gives the impression that congressional investigators and executive withholders live in a perpetual state of tension, but the realities may be along the line of a Department of Defense report that during three years it complied with 300,000 inquiries from Congress but refused to comply with only thirteen. ${ }^{9}$ The executive branch usually states the privilege in absolute

(1963); Hearings before the Subcommittee on Administrative Practice and Procedure of the Senate Judiciary Committee on S. 1966 and S. 1663, Freedom of Information, 88th Cong., 2d Sess. (1963); Hearings before the Subcommittee on Constitutional Rights of the Senate Judiciary Committee on S. 921, Freedom of Information and Secrecy in Government, 85th Cong., 2d Sess. (1958).

For discussions and significant action on the floor of each House, see 103 Cong. REc. 7491-92; 104 CoNG. REc. 6547-75; 104 CoNG. REC. 15688-99; 110 CoNG. REC. 17086-89; 110 CONG. REc. 17666-68; 111 CoNg. REc. 26820; 112 CoNg. REC. 13007.

7 Letter from President Eisenhower, Hearings Before the Subcommittee on Constitutional Rights Senate Committee on the Judiciary, Freedom of Information and Secrecy in Government, 85th Cong., 2d Sess., at 271 (1958).

8 The claim was that not only the President but also department heads could withhold information "where, in their own judgment, the disclosure would, on public considerations, be inexpedient." Hearings, id. at 63-146.

9 Letter from Department of Defense, Hearings, $i d$. at 385-87. 
terms, but it recognizes the constitutional power of Congress to investigate, and practical accommodations are normally made.

Issues about the extent of executive privilege have been numerous and complex. The doctrine is in part constitutional law but the extent to which it is common law or constitutional law remains uncertain,

- and no court has considered the doctrine in a context of executive withholding of information from Congress. Yet the practice about withholding from Congress and the case law about withholding from courts make two major propositions reasonably clear: (1) A doctrine of executive privilege unquestionably exists. (2) Courts which have jurisdiction to consider problems of executive privilege participate in determining the scope of the privilege. Both these propositions were recognized by the Supreme Court in the key case of United States $v$. Reynolds. ${ }^{10}$

A well-drafted Information Act could adopt those portions of the doctrine of executive privilege which are sound and practicable and could probably provide leadership for working out the refinements of the doctrine, so that, in effect, the constitutional law, the common law, and the statutory law would coalesce. But the Information Act misses by a wide margin any such accomplishment. Instead, the fourth exemption seems capriciously to adopt executive privilege completely for commercial or financial information and to reject it completely for non-commercial and non-financial information. ${ }^{11}$

Because executive privilege seems to me vital in the solution of problems under the Information Act, I am surprised that the Attorney General's Memorandum does not mention it. The Department of Justice as recently as 1965 took an official position that in withholding information "the Executive is accountable only to the electorate. Under the separation of powers concept, Congress cannot transfer responsibility for Executive records to the courts."12 That position seems to me extreme, just as the opposite position that the courts may take the whole

10345 U.S. I (1953). Widows of men killed in the crash of a bomber testing secret equipment sued under the Tort Claims Act and sought production of the Air Force's official accident investigation report. The Secretary of the Air Force stated in a letter to the district court that "It has been determined that it would not be in the public interest to furnish this report." The Supreme Court held that the claim of privilege under Rule 34 of the Federal Rules of Civil Procedure was valid, that "the privilege against revealing military secrets" was ". . . well established in the law of evidence," $i d$. at 6-7, and that "Judicial control over the evidence in a case cannot be abdicated to the caprice of executive officers. Yet we will not go so far as to say that the court may automatically require a complete disclosure to the judge before the claim of privilege will be accepted in any case." Id. at 9-10.

11 See $\S 19$ infra.

12 Statement of Norbert Schlei, Assistant Attorney General, Hearings Before the Subcommittee on Administrative Practice and Procedure of the Senate Judiciary Committee on S. 1160, S. 1336, S. 1758, and S. 1879, 89th Cong., 1st Sess. 192, 205 (1965). 
power away from the executive would be extreme; the long-term constitutional solution is likely to follow the middle position of the Reynolds case $^{13}$ that the executive determines the scope of executive privilege, subject to a judicial check whenever a court has jurisdiction. ${ }^{14}$

\section{The Act Governs Disclosures to the Public and Precludes Balancing of Private Interests}

The Act's sole concern is with what must be made public or not made public. The Act never provides for disclosure to some private parties and withholding from others. The main provision of section 3 says that information is to be made available "to the public" and the central provision of subsection (c) requires availability of records to "any person."

That required disclosure under the Act can never depend upon the interest or lack of interest of the party seeking disclosure is emphasized by the history. The previous section 3 provided for disclosure "to persons properly and directly concerned." That was changed to "any person."

One consequence is legislative departure from the customary practices of normal people, who often disclose to those having a special reason for knowing and withhold from those who do not. Private practices frequently depend on the difference between disclosure to the public and disclosure to one person or a restricted few. An individual employer would not make public his appraisal of an employee but he will disclose it to a prospective employer who inquires. Individuals would not make public many of the confidences they do not hesitate to share with colleagues, secretaries, wives, and others. But under the Act, Uncle Sam's information is either made public or not made public. The Act never requires it to be protected from all except those who have a special need for it.

Another consequence of limiting the Act's provisions to disclosures "to the public" and "to any person" is to preclude the balancing of the interest of one private party against the interest of another private party. For instance, the sixth exemption in subsection (e) authorizes withholding of medical files if disclosure "would constitute a clearly

13 United States v. Reynolds, 345 U.S. 1 (1953).

14 Under such cases as Federal Radio Commission v. General Elec. Co., 281 U.S. 464 (1930), separation of powers is violated when a de novo review provision requires a court to perform a nonjudicial function. The argument of the Department of Justice seems to be that this doctrine invalidates the Information Act's requirement of de novo review of withholding information. But no step a court takes in such de novo review is nonjudicial -neither finding facts nor interpreting the Act nor applying constitutional law of executive privilege nor applying common law of executive privilege. 
unwarranted invasion of personal privacy." If the officer or judge finds that the disclosure will be an unwarranted invasion but is in doubt whether it is "clearly unwarranted," a natural approach to decision would be to weigh the privacy interest against the interest of the party seeking the information, so that disclosure would be made to one with a legitimate need but not to one who is malevolently motivated or an officious intermeddler. But under the Act such a balancing is inappropriate. All parties are equal in satisfying the words "any person."

\section{The Act Never Forbids Disclosure but Other Law May}

The Act contains no provision forbidding disclosure. It requires disclosure of all records except what is "specifically" within the nine exemptions and other provisions. The exemptions protect against required disclosure, not against disclosure. The Act leaves officers free to disclose or withhold records covered by the exemptions, but they may then be governed by other statutory law, by the common law, by executive privilege, by executive orders, or by agency-made law in the form of regulations, orders, or instructions. Many statutes confer discretionary power upon agencies to disclose or not disclose specified information, and many statutes require or prohibit such disclosure. ${ }^{15}$

Although disclosure required by the Information Act is always to the public or to "any person," other law many require or permit disclosure to one or to a few, and it may require or permit a balancing of the interests of private parties on both sides. When the Information Act does not require disclosure and other identifiable law is not controlling, the custodian of the information presumably has discretionary power to determine whether and what to disclose and to whom. ${ }^{16}$

A crucial observation that some will find regrettable is that apparently no federal statute of general applicability forbids federal agencies or employees to make disclosures that would constitute clearly unwarranted invasions of personal privacy. ${ }^{17}$

15 See $\$ 18$ infra.

16 For instance, the Department of Justice has vast records about those who have been considered for appointments to the bench. Many items are unfavorable to individuals, whether or not they are now judges. Apparently without violating any law, an officer who has access to those records can disclose them to any outsider. As a practical matter, the officer can unfairly favor one outsider over another and he can allow access that should be denied. Judicial review of such discretion may be theoretically available but may be seldom practical. See 1 Davis, Administrative Law Treatise $\$ 3.13$ (1958).

17 Of course, federal employees are often forbidden by agency rules or instructions to make unauthorized disclosures. The so-called "Housekeeping Statute," 5 U.S.C.A. \$ 301 (1966), authorizes the head of each department to govern "custody, use, and preservation" of records. It was amended in 1958, however, to make clear that it "does not authorize withholding information from the public or limiting the availability of records to the public." The Court held in United States ex rel. Touhy v. Ragen, 340 U.S. 462 (1951), 
6. Discretion of an Equity Court to Refuse Enforcement of the Act

The Information Act contains no mandatory provision for its judicial enforcement. The key words are: "Upon complaint, the district court ... shall have jurisdiction to enjoin the agency from withholding of agency records and to order the production of any agency records improperly withheld from the complaint." The court has jurisdiction to enforce; it is not commanded to enforce. Furthermore, the word "enjoin" is enough to invoke the traditions of equity. And an equity court by its intrinsic nature has a discretionary power to refuse to participate in bringing about results that are inconsistent with sound equitable practice.

Even though the Emergency Price Control Act of 1942 provided that an injunction "shall be granted" against a violation, the Supreme Court held "we do not think that under all circumstances the court must issue the injunction or other order which the Administrator seeks."18 The Court emphasized the fundamental character of equity jurisdiction: "The qualities of mercy and practicality have made equity the instrument for nice adjustment and reconciliation between the public interest and private needs as well as between competing private claims." 19 The Court accordingly upheld a refusal to enjoin violations resting on "mistakes ... made in good faith ..."

When the Supreme Court so holds even under a statutory provision that an injunction "shall be granted," surely equitable traditions apply under the Information Act's provision that the court "shall have jurisdiction ..."

When a public interest is involved, not merely a private interest, the reasons for the equitable tradition are all the stronger: "Courts of equity may, and frequently do, go much farther both to give and withhold relief in furtherance of the public interest than they are accustomed to go when only private interests are involved."20

The equity practice is clear and strong. The court that has jurisdiction to enforce the Information Act also has jurisdiction to refuse to enforce it whenever equity traditions so require.

that an employee of the Department of Justice may obey a Department regulation in refusing to obey a subpoena, but the Court was not passing upon the power of the Attorney General. An especially informative case about power to withhold information is Appeal of the United States Securities and Exchange Commission, 226 F.2d 501 (6th Cir. 1955).

18 The Hecht Co. v. Bowles, 321 U.S. 321,328 (1944).

19 Id. at $329-30$.

20 United States v. First National City Bank, 379 U.S. 378, 383 (1965), quoting with approval from Virginian R. Co. v. Federation, 300 U.S. 515, 552 (1937). 


\section{Publication in the Federal Register}

Subsection (a) prescribes what must be published in the Federal Register. The main items are descriptions of organization, formal and informal procedures, rules of procedure, substantive rules of general applicability, statements of general policy or interpretations of general applicability, and amendments of the foregoing.

The nine or more minor changes from the previous section 3 are quite complex. They are comprehensively explained in the Attorney General's Memorandum, ${ }^{21}$ and I shall not duplicate that long discussion. Instead, I shall comment on the one significant change that is likely to be most troublesome, with respect to which I am inclined to question the Attorney General's position.

The previous section 3 required publication of "substantive rules adopted as authorized by law and statements of general policy or interpretations formulated and adopted by the agency for the guidance of the public, but not rules addressed to and served upon named persons in accordance with law." The requirement was largely ineffective because agencies often deemed policy statements and interpretations to be more for guidance of particular parties or staff than for public guidance. The revision requires publication in the Federal Register of "substantive rules of general applicability adopted as authorized by law, and statements of general policy or interpretations of general applicability formulated and adopted by the agency."

The requirement with respect to rules is limited to those "adopted as authorized by law" and that probably means rules pursuant to the rule-making procedure prescribed by the APA. ${ }^{22}$

The troublesome problem is to find the meaning of the two terms, "statements of general policy" and "interpretations of general applicability." In finding that meaning, we must take account of the provision of subsection (b) requiring availability of "those statements of policy and interpretations which have been adopted by the agency and are not published in the Federal Register." Putting (a) and (b) together, "statements of policy" must be available and "statements of general policy" must be published; "interpretations which have been adopted by the agency" must be available and "interpretations of general applicability" must be published.

21 ATr'y Gen. MEMo. 4-13.

22 The deletion of the words "but not rules addressed to and served upon named persons in accordance with law" does not make the requirement applicable to rules announced in adjudicatory opinions because the reason for the deletion was that the same thought is adequately expressed by the words "of general applicability." SEN. REP. 6. But rules announced in adjudicatory opinions must be published if they are either "statements of general policy" or "interpretations of general applicability." 
On the problem of what is "general" or "of general applicability" the committee reports and the rest of the legislative history furnish no help. The answer must be based on word analysis and practicalities.

In adjudicatory opinions, what policy statements are "statements of general policy" and what interpretations are "of general applicability" -all, or some, or none?

I think the answer has to be some. It cannot be all, because the determination of a unique question is not "general" or "of general applicability." The answer cannot be none, because adjudicatory opinions do often contain statements of general policy or interpretations of general applicability. For instance, to choose a clear example, the National Labor Relations Board in the General Cable case announced in its opinion: "Today, a decade and a half following the establishment of the Board's basic 2-year contract-bar rule, we enlarge the 2-year period to 3, making no other changes." 23 The context shows that the Board was making a new policy or interpretation for all parties, not just the parties before it." The 3-year rule seems to me clearly a "statement of general policy."

But what about the practicality of publishing such a policy statement in the Federal Register? I think the 3-year rule should have been so published; indeed, I think that rule-making procedure should have been followed for formulating the rule. ${ }^{25}$ Furthermore, a very useful purpose will be served if agencies are required to publish in the Federal Register their especially significant statements of general policy or interpretations of general applicability. Such publication will call attention to the legislative quality of such statements and interpretations and to the appropriateness of rule-making procedure. Yet, for practical reasons, I would draw the line closer to cases resembling the General Cable case than to unique cases at the other end of the scale.26

The Attorney General's Memorandum takes the position that no statement of policy in an adjudicatory opinion can be "general" and that no interpretation in such an opinion can be "of general applicability." It says that

... an agency is not required under subsection (a) to publish in the Federal Register the rules, policies and interpretations

23 General Cable Corp., 139 N.L.R.B. 1123, 1125, 51 L.R.R.M. 1444 (1962).

24 Not until the last paragraph of the opinion did the Board say: "Turning now to the instant case and applying the above policy ..." 139 N.L.R.B. at 1129,51 L.R.R.M. at 1447.

25 Reasons are spelled out in 1 Davis, Admisistrative Law Treatise $\S 6.13$ (Supp. 1965).

26 For reasons in support of the view that the old $\S 3$ of the APA required publication in the Federal Register of many opinions accompanying adjudicative orders, see Newman, Government and Ignorance-A Progress Report on Publication of Federal Regulations, 63 HARV. L. REV. 929, 936-37 (1950). 
formulated and adopted in its published decisions. Instead, this "case law" is to be "made available under subsection (b)." (H. Rept., 7.) ${ }^{27}$

The reference to the House committee has to do with subsection (b), not with subsection (a), and the committee says merely that the bureaucracy's case law must be available for inspection. Of course it must. And in addition, in my opinion, the case law that contains "statements of general policy" or "interpretations of general applicability" must be published in the Federal Register, because subsection (a) says so. To reason that because case law must be open to inspection "statements of general policy" and "interpretations of general applicability" need not be published in the Federal Register would be to indulge in a clear non sequitur. The Attorney General merely states his conclusion without supporting reasoning, without setting forth an analysis of the words of subsection (a), and without mentioning the advantages of Federal Register publication in such a case as General Cable.

Apart from adjudicatory opinions, what statements of general policy or interpretations of general applicability must be published? The Attorney General's Memorandum does not discuss this question. For instance, the Internal Revenue Service publishes in its Cumulative Bulletin its "revenue rulings," which are designed to serve as precedents, but it neither publishes nor opens to public inspection its "letter rulings," which are not designed to serve as precedents. Since all revenue rulings are planned as guides to tax law, they all seem to be "interpretations of general applicability" and therefore must be published in the Federal Register, if the clear statutory words are to be followed. I recognize that publication in the Cumulative Bulletin is satisfactory and that duplication of publication is undesirable, but Congress seems to have spoken with clarity. The alternative would be to say that an interpretation which is intended to have general applicability is not an interpretation of general applicability.

\section{Opinions, Orders, and Votes}

Subsection (b) requires opening to public inspection "all final opinions (including concurring and dissenting opinions) and all orders made in the adjudication of cases," and subsection (d) requires such opening of "a record of the final votes of each member in every agency proceeding."

The United States Parole Board never gives reasons for denying a written application for parole; this is a flagrant and long continuing 
violation of section $6(\mathrm{~d})$ of the APA. ${ }^{28}$ The Board can be required to give reasons, and under the new Act it has no excuse for refusing to open them to public inspection. The Federal Deposit Insurance Corporation recently refused to answer reasonable questions as to whether any of its members dissented from the granting of a license; ${ }^{29}$ such a refusal would violate subsection (d) of the new Act. An "order" may say no more than "application granted" or "application denied," but that much has to be open to public inspection; whether that much may be meaningful has to depend upon the application of the Information Act to the other papers in the case.

"Order" and "adjudication" are much broader concepts under section 2 of the APA than one not familiar with section 2 might suppose. Section 2(d) provides: "'Order' means the whole or any part of the final disposition ... of any agency in any matter other than rule making but including licensing." The Attorney General's Memorandum refers to this definition and says:

Neither the previous section 3 nor the revised section contemplates the public availability of every "order" as thus defined. The expression "orders made in the adjudication of cases" is intended to limit the requirement to orders which are issued as part of the final disposition of an adjudicative proceeding. ${ }^{30}$

I think the Memorandum is clearly mistaken because section 2(d) also provides: " 'Adjudication' means agency process for the formulation of an order." Under the APA definitions, every order is issued as part of the final disposition of an adjudication. Therefore, the correct statement is precisely the opposite of what the Attorney General says: Both the previous section 3 and the revised section contemplate the public availability of every "order" as defined by section 2(d).

The auditing of a single tax return may involve dozens of orders and dozens of adjudications, as defined. Each of the million licenses issued

28 Section 6(d), now 5 U.S.C. $\$ 555$ (1966), requires prompt notice of denial of a written application and provides: "Except in affirming a prior denial or when the denial is selfexplanatory, the notice shall be accomplished by a brief statement of the grounds for denial."

29 Washington Post, Sept. 2, 1966, tells the story of the FDIC's grant of insurance for a bank, although the applicant, "an affable and affluent wholesaler of Arkansas land and liquor," was reportedly disapproved by the examiners. The sophisticated reporter said: "The whole affair is 'classified' so far as FDIC is concerned. Chairman Randall won't even confirm that he voted to insure the bank. His position is that the internal workings of FDIC are "confidential and privileged.'" The General Counsel of FDIC has confirmed these facts to me.

30 ATt'y Gen. MeNo. I5. 
annually by the FCG is an adjudication, even if automatically issued. Every one of the Immigration Service's 700,000 dispositions of applications annually is clearly an order; when an officer checks one of thirty reasons on a printed card, the check-mark is an opinion. ${ }^{31}$ "Any matter other than rule making" includes no-action letters of the SEG and informal merger clearances by the FTC or the Antitrust Division; these materials, not heretofore available for public inspection, clearly should be and clearly will be under the Act, except to the extent that facts stated are within an exemption.

\section{Statements of Policy and Interpretations}

Subsection (b) requires opening to public inspection "those statements of policy and interpretations which have been adopted by the agency and are not published in the Federal Register."

The FCC once debated for half a day whether to set a broadcast renewal application for hearing; the debate crystallized an issue of policy. Three commissioners voted to set the case for hearing and four voted not to. The outside world, including the applicant, never learned that the question was even considered. The determination of policy was fully stated in the Commission's confidential minutes. The Act requires disclosure of such minutes, unless they are an intra-agency memorandum within the meaning of the fifth exemption..$^{32}$

Other such questions about "statements of policy" are affected by the same considerations as apply to "interpretations," to which we now turn.

An important body of law heretofore kept mostly secret is the vast accumulation of SEC no-action letters. Such a letter typically states that the Commission's staff will recommend no action against the applicant for doing what the applicant has proposed to do. Such letters are orders and they are also interpretations of law or facts. Facts stated in such letters may sometimes be exempt from disclosure under the fourth exemption, but the "interpretations" must be made available under subsection (b). A representative of the SEG has argued before an audience that letters by the Commission's staff are not "interpretations which have been adopted by the agency," but that argument seems to me without merit. The staff is authorized, the Commission supervises, the Commision has never refused to honor such a letter, and most of what the Commission does it does through its staff. Furthermore, the staff is an "agency" within the definition in section 2 of the APA.

The term "interpretations which have been adopted by the agency"

31 But see text accompanying note 114 infra.

32 See discussion of the fifth exemption in \$ 21 infra. 
seems clearly to include not only the Internal Revenue Service's revenue rulings, heretofore published in the Cumulative Bulletin, but also the so-called letter rulings, heretofore not only unpublished but also closed to public inspection. ${ }^{33}$ The theory of the letter ruling has been that it is not carefully enough considered to serve as a precedent for other cases. ${ }^{34}$ Subsection (a) requires "interpretations of general applicability" to be published in the Federal Register and subsection (b) requires availability of "interpretations which have been adopted by the agency"; the natural line of distinction is use or nonuse of the interpretations as precedents.

The face of the Act seems clear but we still must examine the complex legislative history. The Senate committee merely restates the words of the bill.35 The House committee says that subsection (b) "would require agencies to make available statements of policy, interpretations .... This material is the end product of Federal administration. It has the force and effect of law in most cases, yet under the present statute these Federal agency decisions have been kept secret from the members of the public affected by the decisions." 36 Some of what the House committee says here is necessarily so. Suppose, for example, that a letter ruling gives taxpayer $\mathrm{X}$ a favorable interpretation; surely the interpretation has "the force and effect of law" in X's case. Using the House committee's implicit reasoning that what has the force and effect of law must be disclosed, the letter ruling must be disclosed.

The House committee goes on to say that "the bureaucracy has developed its own form of case law. This law is embodied in thousands of orders, opinions, statements, and instructions issued by hundreds of agencies. This is the material which would be made available under subsection (b) . . . ." I do not see how any reasonable person could

33 See Rogovin, The Four R's: Regulations, Rulings, Reliance and Retroactivity, 43 TAXEs 756, 764-66 (1965): "In contrast to a letter ruling a 'Revenue Ruling' is an official interpretation by the Service, issued only by the National Office and published in the Internal Revenue Bulletin ... . The Service selects for publication all letter rulings having substantial value as precedents ... . Basically, however, both the Revenue Ruling and the letter ruling constitute an interpretation of the Code with respect to a particular state of facts."

The Internal Revenue Service issues about 30,000 rulings per year. The recent Cumulative Bulletins contain only about 360 per year. This means that only a little more than one per cent are published. Under the Information Act, all are required to be open to public inspection.

34 "No unpublished ruling or decision will be cited or relied upon by any officer or employee of the Internal Revenue Service as a precedent in the disposition of other cases." Preface to each recent volume of the Cumulative Bulletin.

35 SEN. REP. 6.

36 House REP. 7. As to the House committee's statement that "interpretations" are "the end product of Federal administration," see § 11 below. 
disagree with this passage. The case law of the agencies has to be available for public inspection. The statute so requires. Fairness so requires.

But the House committee then contradicts itself:

However, under S. 1160 an agency may not be required to make available for public inspection and copying any advisory interpretation on a specific set of facts which is requested by and addressed to a particular person, provided that such interpretation is not cited or relied upon by an officer or employee of the agency as a precedent in the disposition of other cases. ${ }^{37}$

This statement, in my opinion, is not the law, even though the Attorney General's Memorandum, without explanation, quotes it with approval. ${ }^{38}$ It is contrary to the needs of fairness, contrary to the House committee's earlier statements, contrary to the report of the Senate committee, and contrary to the clear words of the statute. If a letter ruling interprets tax law in favor of $\mathrm{X}$, fairness requires that $\mathrm{Y}$ who has the same problem should have opportunity to know the interpretation in $\mathrm{X}$ 's case. The House committee's earlier statement that an agency's "case law" must be available is in accordance with the statute. The Senate committee was faithful to the plain statutory meaning. The statutory words that every agency must make available "interpretations which have been adopted by the agency" are unqualified. Nothing on the face of the Act supports the House committee's statement that an interpretation not relied upon as a precedent need not be made available.

True, the last sentence of subsection (b) says: "No . . . interpretation ... may be relied upon, used or cited as precedent by an agency against any private party unless it has been ... made available or published ...." These words clearly do not say that an interpretation need not be made available if it is not used as a precedent. What the statute requires is one thing; what the sanctions of the statute reach is quite another. Congress is entitled, if it chooses, to enact mandatory requirements for the government's officers and to support them with full enforcement machinery, with no enforcement machinery, or with partial enforcement machinery. The scope of the requirements should not be measured by the sanctions. I specifically disagree with the Attorney General's Memorandum: "The scope of this sanction seems to limit the effective reach of subsection (b) to those orders which may have precedential effect." 39 This seems to me mistaken in two respects:

37 House REP. 7.

38 Att'y Gen. Memo. 16.

39 Id. at 15 . 
(1) Even if "the effective reach" of a mandatory statute were measured by the enforcement machinery, the effective reach would not be "those orders which may have precedential effect" but it would be only those orders which operate "against any private party" and may have precedential effect; the effective reach would not extend to orders operating in favor of a private party. (2) In my opinion, the Attorney General should not tell government officers that lack of enforcement machinery means they are free to violate clear statutory requirements. The Attorney General should insist that government officers obey mandatory statutes whether or not enforcement machinery is provided.

Furthermore, I think subsection (b) is enforceable not only through the no-reliance-no-citation provision but also by getting a court order, for reasons stated in the next section.

\section{Judicial Enforcement of Subsection (b)}

The House committee's remark just considered may have rested on the assumption that subsection (b) is not judicially enforceable, and the Attorney General's Memorandum silently assumes at two points that it is not, without supporting analysis. ${ }^{40}$

My opinion is that subsection (b) is judicially enforceable-both pursuant to the Act's provisions and apart from the Act. The statutory language is clear: Subsection (c) requires disclosure of "records," an interpretation in an agency's file is a record, and a court has jurisdiction to "order the production of any agency records improperly withheld from the complainant." True, subsection (c) has an "except" clause: "Except with respect to the records made available pursuant to subsection (a) and (b), every agency shall ... make records promptly available to any person." But one can hardly read "records made available" to mean "records not made available" or "records improperly withheld."

The "except" clause is without sensible meaning, since it excepts "records made available" from the requirement that records be made available, and therefore one might argue that it must be given meaning different from the meaning it has on its face. Even so, "records made available" cannot mean "records not made available." A possible

40 The implication appears at page 15 when the Memorandum says: "The sanction applicable to subsection (b) is set forth in its last sentence." The implication also seems to appear at page 23 when the Memorandum says: "The 'Except' clause with which the provision begins is intended to emphasize that the agency records made available by subsections (a) and (b) are not covered by subsection (c) which deals with other agency records.' (S. Rept., 89th Cong., 2)." In this statement and quotation, the Attorney General seems to join in the assumption of the Senate committee that "records made available" means "records improperly withheld"-an assumption shortly to be discussed. 
reading would build on the idea that the statute, not the agency, makes records available, and that the "except" clause applies to records the statute has made available, so that the "except" clause would be read as if it said: "Except with respect to records made available by subsections (a) and (b) ...." But the statute does not say "by"; it says "pursuant to." 41 One cannot say that the statute makes records available pursuant to the statute; one must say that the agency makes records available pursuant to the statute. So the Information Act nonsensically excepts records the agency has made available from its requirement that the agency make records available.

In the face of these analytical considerations, a court would have to strain to find that subsection (b) is not judicially enforceable. But a discerning court would be inclined to strain in the opposite direction, if need be, because judicial enforcement is so clearly desirable. In absence of judicial enforcement, the only enforcement of subsection (b) would rest on its last sentence:

No final order, opinion, statement of policy, interpretation, or staff manual or instruction that affects any member of the public may be relied upon, used or cited as precedent by an agency against any private party unless it has been indexed and either made available or published as provided by this subsection or unless that private party shall have actual and timely notice of the terms thereof.

If this provision were the only means of enforcement, subsection (b) would be without any means of enforcement most of the time. An agency usually produces its case law supporting its position against a private party, but it cannot always be counted on to disclose case law favorable to a private party. The provision fails to reach the disclosure of materials that favor the private party.

Even if the Act did not provide for judicial enforcement of subsection (b), the courts could enforce it apart from the Act. Federal courts have a general equity jurisdiction, and the APA provides that final agency action is reviewable except to the extent that statutes preclude judicial review or agency action is committed to agency discretion by law. ${ }^{42}$ No statute precludes review, and action in violation of a mandatory statute is not committed to agency discretion by law. The Attorney General's Memorandum makes the assumption of judicial unenforcea-

41 The Senate committee, however, in explaining its addition of the "except" clause, used the word "by" instead of the words "pursuant to": "This is a technical amendment to emphasize that the agency records made available by subsections (a) and (b) are not covered by subsection (c) which deals with other agency records." SEN. REP. 2.

42 Formerly $\S 10$, now $\$ \$ 701$ and 704 of the codified Act. 
bility of subsection (b) without mentioning the question whether judicial enforcement may be appropriate apart from the specific provisions of the Information Act.

\section{Interpretations Growing out of Such Activities as Investigating, Prosecuting, Negotiating, Settling, Litigating}

A question of great importance, not mentioned by the Attorney General's Memorandum, is whether the Act requires availability of all interpretations, including those made through processes other than adjudication and rule making, or whether the requirement of availability is limited to interpretations embodied in the end product of administration.

Subsection (b) requires disclosure of "interpretations which have been adopted by the agency." Nothing on the face of the Act says that the interpretations to be disclosed must be embodied in a final order or rule. From the face of the Act one would expect that "interpretations" means all interpretations. ${ }^{43}$

The Senate committee, by merely repeating the Act's words, seems to say that the provision applies to all interpretations. ${ }^{44}$ But the House committee says that "interpretations" are "the end product of Federal administration." 45 Yet that statement is in the form of a statement of fact, not a statement of intent, and as a statement of fact it seems clearly mistaken; interpretations are made not only as the end product of administration but at any interim stage of administration. Interpretations are made in deciding whether to investigate or to prosecute and what position to take in negotiating, settling, or litigating.

On the question of what meaning should be given to "interpretations," a limitation of the term to the end product of administration would be clearly undesirable, for interim interpretations are in the nature of law, and private parties who are affected by an agency's law should always be entitled to a disclosure of it.

For instance, when much is at stake the careful lawyer who is making thorough preparation for negotiating with an agency may want to know its positions in negotiations with other parties. Indeed, the only "interpretation" having significance to such a lawyer may be those made in prior such negotiations. Similarly, if an agency, wholly or partly on the basis of "interpretations," decides to investigate A but not $B$, to prosecute $\mathrm{C}$ but not $\mathrm{D}$, to settle with $\mathrm{E}$ but not with $\mathrm{F}$, and to litigate with $\mathrm{G}$ but not with $\mathrm{H}$, opening all such interpretations to public inspection

43 For discussion of the absence of the word "all" see note 55 infra.

44 SEN. REP. 6.

45 HOUSE REP. 7. 
seems clearly desirable. My opinion is that such opening is desirable not only because affected parties should have a chance to know the agency's law but also because public criticism may have a salutary effect on the agency and its staff.

Because of this clear desirability, I would interpret the Act in accordance with its literal words and in accordance with the Senate committee report, and I would reject the somewhat ambiguous statement of the House committee that interpretations are the end product of administration.

If my interpretation is correct, a further observation necessarily follows: The Attorney General and all his subordinates, including every United States Attorney, are all "agencies" within the meaning of the APA, so that all "interpretations" by any one of them are required to be available for public inspection, unless an exemption applies. And the term "interpretations" covers a great deal. It probably applies whenever law is applied to particular facts, including even such consent arrangements as a plea of guilty to a lesser charge.

\section{Administrative Staff Manuals and Instructions}

Subsection (b) requires every agency to make available for public inspection "administrative staff manuals and instructions to staff that affect any member of the public." An earlier version of the bill did not contain the word "administrative" and the Senate committee explained the addition of that word:

The limitation of the staff manuals and instructions affecting the public which must be made available to the public to those which pertain to administrative matters rather than to law enforcement matters protects the traditional confidential nature of instructions to Government personnel prosecuting violations of law in court, while permitting a public examination of the basis for administrative action.48

Since the word "administrative" was added to say what the Senate committee says, the committee statement is probably the law. The committee's dichotomy at first seems to be "administrative matters" and "law enforcement matters." But that raises the question how to classify administrative enforcement of law, and the committee explains that law enforcement means "prosecuting violations of law in court." So the dichotomy turns out to be enforcement in court and enforcement in an agency. But no rational reason supports that. If both the

46 SEN. REP. 2, Amendment No. 1. 
Antitrust Division and the Federal Trade Commission instruct their staffs as to what mergers should be prosecuted, I think the instructions should be subject to compulsory disclosure to the extent that they involve interpretation of law and only to that extent. Yet if the Senate committee's statement is followed, all the instructions to the Trade Commission's staff and none of the instructions to the Antitrust Division's staff will have to be disclosed.

The House committee's interpretation is along a different line and is not much better: "[A]n agency may not be required to make available those portions of its staff manuals and instructions which set forth criteria or guidelines for the staff in auditing or inspection procedures, or in the selection or handling of cases, such as operational tactics, allowable tolerances, or criteria for defense, prosecution, or settlement of cases." 47 Since the statute requires availability of administrative staff manuals and instructions that affect any member of the public, the House committee's statement that portions of administrative staff manuals and instructions that affect any member of the public need not be available seems to contradict the statute. Furthermore, the House committee's statement differs from the Senate committee's. In this circumstance, the words of the statute must control unless such a result is impracticable; I firmly believe that staff manuals or instructions in the nature of substantive or procedural law should be available. For instance, "guidelines for the staff in auditing" of tax returns ought to be open to the taxpayer to the extent that they tell the auditor the position of the Internal Revenue Service on any question of tax law. Furthermore, contrary to what the House committee says, I think a portion of "guidelines for the staff ... in the selection or handling of cases . . or criteria for defense, prosecution, or settlement of cases" should be open to inspection by any party affected by them. I agree that secrecy is desirable to the extent that policies about prosecuting depend upon such strategies as inducing maximum compliance with the least expenditure.

The opinion I have just expressed about what is desirable seems to me closer to what the statute says than the statements of the two committees, which differ from each other and differ from the statute. When the materials emerging from the legislative process are so confused, an interpreter must be guided in part by what he believes to be a sound system. One fundamental principle is that secret law is an abomination.

Yet I feel obligated to bring out an argument against the conclusion

47 HOUSE REP. 7-8. 
just stated. In 1964 I suggested to the Senate subcommittee a requirement about disclosure of staff manuals. ${ }^{48}$ In 1965 I said to the subcommittee:

Section 3(b) adopts many of my suggestions of last year, and I think it is greatly improved. One of my suggestions, however, has been carried too far. I recommended that a provision be included to require opening to public inspection the portions of operating instructions to an agency's staff that amount to substantive law. . . . Opening to the public all instructions "that affect any member of the public" goes too far and needs to be cut back. For instance, one who is investigated may be affected by instructions to the investigator about how to investigate, but some such instructions are properly confidential. I recommend that the provision be revised to read as follows: "staff manuals and instructions to staff to the extent that they embody agency interpretations of law." 49

Since the subcommittee and hence Congress did not adopt this recommendation, can the Act be interpreted as if the recommendation had been adopted? The only merit of an affirmative answer is that it is desirable and that every available alternative has less merit.

The Attorney General's Memorandum concludes that manuals and instructions should be available after deletion of "standards and instructions which necessarily cannot be disclosed to the public."50 This is sound as far as it goes, but the guidance can and should be more specific.

\section{Deleting Identifying Details}

Subsection (b) provides: "To the extent required to prevent a clearly unwarranted invasion of personal privacy, an agency may delete identifying details when it makes available or publishes an opinion, statement of policy, interpretation, or staff manual or instruction: Provided, That in every case the justification for the deletion must be fully explained in writing."

May an agency delete identifying details in order to prevent a clearly unwarranted disclosure of commercial or financial information a corporation has submitted to the agency in confidence? Clearly an agency

48 Hearings Before the Subcommittee on Administrative Practice and Procedure of the Senate Judiciary Committee on S. 1663, Administrative Procedure Act, 88th Cong., 2d Sess. 244, 273 (1964).

49 Hearings Before the Subcommittee on Administrative Practice and Procedure of the Senate Judiciary Committee on S. 1160, S. 1336, S. 1758 and S. 1879, Administrative Procedure Act, 89th Cong., Ist Sess. 138, 178 (1965).

50 AtT'y Gen. Memo. 17. 
should have such power, even though the bad draftsmanship says otherwise. For instance, because much law is contained in the interpretations embodied in the SEC's no-action letters, the interpretations should be disclosed to affected parties, but the confidential information in the letters should be protected. The easy solution is often to disclose the letters but to delete the identifying details. Yet one probably cannot say that a corporation has a "personal privacy." The ineptitude of the draftsmen should not prevent a sensible result."51

Although the requirement that "the justification for the deletion must be fully explained in writing" at first seems excessive, the Attorney General's Memorandum makes the excellent suggestion that agencies specify in rules the usual reasons for deletions and then cite the rules to help justify deletions. ${ }^{52}$

\section{The Index Requirement}

\section{Subsection (b) provides:}

Every agency also shall maintain and make available for public inspection and copying a current index providing identifying information for the public as to any matter which is issued, adopted, or promulgated after the effective date of this Act and which is required by this subsection to be made available or published.

The requirement is limited to "a current index." Files in existence on July 4, 1967 need not be indexed. Secret law existing at that time may remain secret for want of access to it through an index.

The difficult problem, surprisingly, is whether the statutory requirement of an index for "any matter ... required to be made available" means all matters or only some. From the face of the statute, one would unhesitatingly say that "any matter" in this context means all matters. The Senate committee so assumed. ${ }^{53}$ The House committee said that subsection (b) "requires an index of all the documents having preceden-

51 The Senate committee speaks of "the private citizen's right to be secure in his personal affairs," SEN. REP. 7. The House committee speaks of "the need to protect individual privacy." But the committees' failure to think of corporations was probably an inadvertence.

The Attorney General's Memorandum curiously says at page 19 that the definition of "person" in section 2(b) of the APA includes corporations, and that ". . . the reasons for deleting identifying details would seem as applicable to corporations as to individuals." But the statute does not use the word "person" and the definition of it is therefore irrelevant.

52 AtT'Y Gen. MEMro. 20.

53 "Requiring the agencies to keep a current index of their orders, opinions, etc., is necessary ... This change will prevent a citizen from losing a controversy with an agency because of some obscure and hidden order or opinion ..." SEN. REP. 7. 
tial significance." 54 But this remark is a misfit for half the six items, because the concept of precedential significance is not customarily applied to policy statements, staff manuals, or instructions.55

Taken together, the clarity of the statute and the Senate committee's interpretation of it seem to me to outweigh the House committee's half-wrong statement.

As to what interpretation is desirable, the first step is to recognize that the House committee's remark about precedential significance cannot be used to limit the indexing of policy statements, manuals, or instructions. Indexing seems to me especially desirable for opinions and interpretations. They contain a high proportion of useful case law of the agencies, and I insist that all law should be available to affected parties. Some opinions may have little value, but I would prefer to have all of them available and indexed than to have agencies select the ones they believe to have precedential significance. A private party who wants to know the agency's law should be entitled to make his own determination of what precedents have value.

If I were making a legislative choice, however, I would not require the indexing of all orders. One who needs agency case law seldom goes to the orders, which may say only "granted" or "denied." Furthermore, the indexing of all orders may be impracticable-depending on what an index is. The Social Security Administration issues more than four million orders a year, the Bureau of Customs three million orders, the Department of Agriculture two million feed grain and wheat diversion orders, and the FCC more than one million licenses (each an order).

Because I have discovered no analytical means under the statute for requiring the five items, but not orders, to be indexed, and because I think the index requirement should reach all of the five items, I would interpret the statute to require indexing of all six items, but I would interpret "index" to include any classification system that helps find a paper in a mass of files. Probably the most important remark that can be made about the index requirement is that an index need not be alphabetical, or by subject matter, or by numbering, or by names of parties, or by any other particular form of classification.

A single example may provide a lead for further imagination about

54 House REP. 8.

55 Because the 1966 statute says "all" before each of the first two of the six items required to be disclosed but omits "all" before each of the other four, it could mean all orders and all opinions but some policy statements, some interpretations, some staff manuals, and some instructions, but it could not mean some orders and all of each of the other items. The 1967 codification, however, takes care of the problem by omitting "all" before each of the six items, thereby implying "all" before each. 
other types of records: The Immigration Service, I think, already has an index to the 700,000 applications on which it acted last year. Every application is assigned a file number upon receipt by a district office (unless a file already exists). Every application has to be accompanied by a small fee. All the money goes to a cashier, who records the amount, the date, the number of the file, and the nature of the application; these items are printed by the cash register on rolls of tape, and the rolls are systematically kept in each office. The rolls are not sent to the central office in Washington. The rolls seem to me to be an index and to satisfy the statutory requirement.

The Attorney General's Memorandum assumes without discussion that the House committee's half-wrong remark overrides the clear statute and the Senate committee's view. The Memorandum sets forth no analysis of the statutory words, recognizes no difference between orders and the other five items, and does not mention the impropriety of applying the concept of precedential significance to policy statements, manuals, or instructions. As long as the agencies follow the Memorandum, a good many systems of secret law will continue.

The Act's judicial enforcement provision does not reach indexing. ${ }^{56}$

\section{The Nine Exemptions Are Limited to What Is "Specifically Stated"}

Before we consider the nine exemptions one by one, we must observe that each exemption is limited to what is "specifically stated." Subsection ( $f$ ) provides: "Nothing in this section Tthe entire Information Act] authorizes withholding of information or limiting the availability of records to the public except as specifically stated in this section ..." The Senate committee says: "The purpose of this subsection is to make it clear beyond doubt that all materials of the Government are to be made available to the public by publication or otherwise unless explicitly allowed to be kept secret by one of the exemptions in subsection (e)." 87 The House committee's statement is almost the same. ${ }^{88}$

The pull of the word "specifically" is toward emphasis on statutory language and away from all else-away from implied meanings, away from reliance on legislative history, away from needed judicial legislation.

Courts that usually constitute themselves working partners with legislative bodies to produce sensible and desirable legislation may follow their accustomed habits in narrowing the ascertainable mean-

56 The judicial enforcement provision of subsection (c) confers "jurisdiction . . . to order the production of any agency records improperly withheld ...." A nonexistent index cannot be a part of "agency records."

57 SEN. REP. 10.

58 HOUSE REP. 11. 
ing of the words of an exemption, but in some degree they are restricted in following those habits in broadening that meaning. The "specifically stated" restriction operates in only one direction.

When no constitutional problem is involved, may Congress by expressly limiting interpreters to what Congress specifically states require departures from what common sense obviously requires? The answer is clearly yes. Congress unquestionably has the power. But it may be very unwise in exercising this power. Its own competence to make law on a complex subject may be so limited that it should invite, not prevent, the help of administrative and judicial interpreters to make its enactments workable and sensible.

The Attorney General's Memorandum discusses the exemptions one by one, dealing with difficult problems of interpretation, without once mentioning the "specifically stated" clause. 59 Yet my opinion is that that clause is often relevant in determining the proper interpretation of particular exemptions. The Memorandum's only mention of the clause is in its separate discussion of subsection $(f) .{ }^{60}$

\section{National Defense and Foreign Policy}

In late 1961 President Kennedy and his advisers conferred about adding a military force of 15,000 men to the few hundred "military advisers" in Vietnam. Undersecretary George Ball said this would commit the prestige of the United States to the war and asked whether the others were prepared to commit 300,000 Americans to achieve a military solution. Ball said he was not. As Reston tells the story, "Rusk and McNamara both conceded that Ball's question was fair but also said yes, they were prepared to see it through. But the American people were not told that. The decision was seen by the public as a modest increase of the noncombatant American force, signifying no significant change in American policy ..."61 Representatives of the press believe that such a policy choice should not be concealed but should be publicly understood and debated. This is a sample of the belief by the press that is a main political force behind the Information Act.

Yet the Act does precisely nothing to carry out the point of view of the press with respect to national defense and foreign policy. Instead, it strengthens the President's hand in withholding information on those subjects. The first exemption relieves from required disclosure "matters that are ... specifically required by Executive order to be

59 ATT'Y GeN. MEMO. 29-39.

$60 I d$. at 39.

61 See Reston, The Artillery of the Press 25-26 (1966). 
kept secret in the interest of national defense or foreign policy." Under the Act the President may withhold information about national defense or foreign policy with the formal approval of Congress, previously lacking.

Whether the Act enlarges the executive power to withhold information is unclear. Apart from the Act, a court applying the law of the Reynolds case $^{62}$ may in some circumstances participate in the determination of the scope of executive privilege. The Secretary of the Air Force certified that furnishing the investigation report "would not be in the public interest," and the holding was, in part, that "The court itself must determine whether the circumstances are appropriate for the claim of privilege . . . "63 Under the Act, the Secretary would presumably ask the White House for an executive order, and a presidential assistant would presumably comply. The court then might be bound by the executive order, on the theory that the Act has delegated power to the President. But the argument the other way has merit: The first exemption, like all the other exemptions, merely means that the Act's disclosure requirements do not apply, and when the Act has no effect, the law is what it would have been without the enactment. ${ }^{64}$

\section{Personnel Rules and Practices}

The second exemption applies to "matters that are ... related solely to the internal personnel rules and practices of any agency."

The Senate committee explains: "Exemption No. 2 relates only to the internal personnel rules and practices of an agency. Examples of these may be rules as to personnel's use of parking facilities or regulation of lunch hours, statements of policy as to sick leave, and the like."65 This statement seems fully faithful to the words of the statute.

But the House committee, once again, tries to change the meaning of the legislative language: "Matters related solely to the internal personnel rules and practices of any agency: Operating rules, guidelines, and manuals of procedure for Government investigators or examiners would be all exempt from disclosure . . . ."68

As usual, the Attorney General's Memorandum assumes that what the House committee says is the law. It does not mention that the

62 United States v. Reynolds, 345 U.S. 1 (1953).

$63 \mathrm{Id}$. at 8.

04 The congressional acquiescence does not reach withholding from Congress because subsection ( $f$ ) provides: "[N]or shall this section be authority to withhold information from Congress."

65 SEN. REP. 8.

66 House REP. 10. 
Senate committee said something altogether different. Nor does it set forth an analysis of the statutory words.

My opinion is that the words "internal personnel rules" mean what the Senate committee says, not what the House committee and the Attorney General say. "Operating rules" may be "internal personnel rules" only to the extent that they deal with the relations between an agency and its employees, not to the extent that they deal with the relations between an agency and an outsider or between employees of the agency and an outsider.

The House committee goes on to say that "this exemption would not cover all 'matters of internal management' such as employee relations and working conditions and routine administrative procedures which are withheld under the present law."67 The committee is now going in the opposite direction, but again I must disagree; I think that "employee relations and working conditions" are a part of "internal personnel rules and practices" which may be withheld from disclosure. Of course, "routine administrative procedures" must be not only disclosed but even published in the Federal Register if they affect anyone outside the agency.

No good reason for exempting "internal personnel rules and practices" has ever come to my attention. The exemption seems to me opposed to the basic push to let the public know what the government is doing.

\section{Other Statutes Which Specifically Allow Nondisclosure}

The third exemption covers "matters that are . . . specifically exempted from disclosure by statute."

A very useful compilation of statutes, which says in its preface that it "does not purport to cover all of the Federal statutes," is a House Committee Print, entitled Federal. Statutes on the Availability of Information, for the use of the Committee on Government Information, published in 1960 in 303 pages.

Some of the statutes authorize agencies to determine whether specified information shall be made available to the public. For instance, the Securities Exchange Act authorizes the Commission to "hear objections" and then to make available an "application, report, or document only when in its judgment a disclosure of such information is in the public interest." 68 If the Commission under this provision decides against public disclosure, is the information, within the meaning of the third exemption, "specifically exempted from disclosure

67 Ibid.

6848 Stat. 901 (1934), 49 Stat. 704 (1935), 15 U.S.C. § 78x (1964). 
by statute"? Although a respectable argument may be made that the information is exempted by the Commission and not by the statute, that interpretation will defeat the intent of the Securities Exchange Act, which is more specific than the Information Act; therefore, perhaps the Securities Exchange Act should be deemed to "specifically exempt" whatever information the Commission, acting within the power granted, decides to withhold.

\section{Trade Secrets and Commercial or Financial Information Obtained} from Any Person and Privileged or Confidential

The fourth exemption is probably the most troublesome provision in the Act. Obedience to its rather clear words would be extremely injurious. Some escape from the plain meaning of the statutory words is essential.

The Act provides: "The provisions of this section shall not be applicable to matters that are ... (4) trade secrets and commercial or financial information obtained from any person and privileged or confidential." The troublesome question is what to do about noncommercial and non-financial information which is privileged or confidential. For example, when a government officer induces a corporation to furnish him some non-commercial and non-financial information, with a good faith understanding that the information will be kept confidential, can the fourth exemption be interpreted to protect the information from required disclosure?

The requirements of common sense directly collide with the clear statutory language. Obviously, the good faith understanding that the information will be kept confidential should be honored. But the statutory words clearly limit the exemption to "commercial or financial information." The word "information" is modified by "commercial or financial" and it is also modified by "privileged or confidential." The words plainly limit the exemption to information which is commercial or financial and which is privileged or confidential. Indeed, I think the meaning of the statutory words is not merely reasonably clear but entirely clear.

Even so, some escape is necessary. A possible interpretation would recognize three items that are exempt: (1) "matters that are . . trade secrets"; (2) "matters that are ... commercial or financial information obtained from any person"; and (3) "matters that are ... privileged or confidential." The first and third make sense but the second does not; Congress could not have intended to exempt all commercial or financial information obtained from any person..$^{69}$ Furthermore, cutting up

69 The history of the provision helps to show that the exemption (apart from trade 
the exemption into these three categories does violence to the statutory language because the word "information" is so clearly modified by both "commercial or financial" and "privileged or confidential."

The Attorney General's Memorandum never acknowledges that the statutory words of the fourth exemption have a plain meaning. Instead, the Memorandum says that the words are

... susceptible of several readings, none of which is entirely satisfactory. The exemption can be read, for example, as covering three kinds of matters: i.e., "matters that are * * * [a] trade secrets and $[\mathrm{b}]$ commercial or financial information obtained from any person and [c] privileged or confidential." (bracketed initials added). Alternatively, clause [c] can be read as modifying clause [b]. Or, from a strictly grammatical standpoint, it could even be argued that all three clauses have to be satisfied for the exemption to apply. In view of the uncertain meaning of the statutory language, a detailed review of the legislative history of the provision is important. ${ }^{70}$

Especially fascinating is this sequence: The Attorney General (1) says the statute is susceptible of several readings, (2) he lists those readings, and (3) he then reaches a conclusion different from any he lists! If what he says implies that the statute is not susceptible of the reading he adopts, then I agree! Yet I am in basic sympathy with the Attorney General in all this because I fully agree with the fundamental idea that underlies what he says in the passage quoted-that no reading of which the Act is susceptible can feasibly govern what the agencies will do. The fault is that of Congress, not that of the Attorney General. ${ }^{71}$

Of the three readings the Attorney General lists, he properly rejects the third, for it is utterly preposterous and contrary to the clear words; it would mean that trade secrets are not exempt unless they are com-

secrets) reaches only that information which is privileged or confidential. The 1964 version was: "Every agency shall make all its records promptly available to any person . . . [except] records ... which are ... trade secrets and other information obtained from the public and customarily privileged or confidential." S. 1666, §3(c), as printed in SEN. REP. No. 1219, 88th Cong., 2d Sess. (1964). One could say that this exempts "records . . . which are ... trade secrets" and "records ... which are . . . customarily privileged or confidential," but one is barred by common sense from saying it exempts "records . . . which are ... other information obtained from the public."

70 ATT'Y GeN. Memo. 32. The brackets and the asterisks are those of the Attorney General.

71 The Attorney General's word analysis is not designed to find the proper interpretation but only to find that the statute has "uncertain meaning" and that therefore "a detailed review of the legislative history of the provision is important." I agree that the legislative history is important, but I cannot agree that the statutory words have "uncertain meaning." The only uncertainty I find stems from the undesirability of what the words plainly say, not from the grammatical sense of the statutory words. 
mercial or financial. He properly rejects the first reading because he finds that Congress could not have intended to exempt all commercial or financial information. This leaves the second, which I believe to be fully supported by the clear statutory words; the Attorney General's only reason for rejecting the second is legislative history, to which we now turn.

The most important fact about the legislative history is that no explanation appears for the addition to the fourth exemption of the words "commercial or financial." The 1964 version of the bill (S. 1666) provided for exemption of "trade secrets and other information obtained from the public and customarily privileged or confidential."72 That version was passed by the Senate, but the House did not act, and when the bill (S. 1160) was introduced in the 89th Congress, two changes had been made: The word "customarily" was deleted, ${ }^{73}$ and the words "commercial or financial" were added.74

Not only was no explanation ever made for the addition of the words "commercial or financial," but both the Senate committee and the House committee in their reports seem to read the words "commercial or financial" as if they were not there. Both reports, for instance, say the exemption would cover "information customarily subject to the doctor-patient, lawyer-client, lender-borrower, and other such privileges." 75 Since information within the doctor-patient privilege is normally non-commercial and non-financial, the committees seem to be strangely ignoring the statutory words "commercial or financial." Furthermore, the Senate committee says the exemption includes "any commercial, technical, and financial data," and the House committee says that it includes "technical or financial data." The committees do not attempt to explain how the words "commercial or financial" can be stretched to include "technical." The reports on their face appear to involve a flagrant attempt to defeat the plain meaning of the words "commercial or financial."7e

72 SEN. Rep. No. 1219, 88th Cong., 2d Sess. 6 (1964).

73 The deletion of "customarily" is not explained in a committee report but was discussed on the floor of the Senate. Senator Fumphrey objected to the word, but the bill's sponsor, Senator Long of Missouri, explained that agencies' customs of keeping information confidential should not be the guide. 110 Cong. REc. 17667 (1964). The Senate kept Senator Long's version and passed the bill. But when the bill was introduced in the new Congress, the word "customarily" was deleted without explanation.

74 A third change, later made, substituted "any person" for "the public." This change was designed to cover information obtained from an agency's staff member, that is, information generated by the agency.

75 SEN. REP. 9; House REP. 10.

76 The most appealing passage, which in my opinion ought to be the law with respect to all information but clearly is not the statutory law with respect to non-commercial and 
But the discrepancy between the statutory language and the reports turns out to be a mere inadvertence. The Senate committee simply failed to alter its earlier report, based on the earlier bill without the words "commercial or financial," to reflect the addition of the words "commercial or financial." 77 And the House committee seven months later copied most of the Senate committee report.78

Committee reports explaining the earlier version of the bill that did not include the words "commercial or financial" do not seem to me to be a satisfactory basis for finding the meaning of the enacted version that did include those words. ${ }^{79}$

Yet the Attorney General's Memorandum concludes that Congress did not intend to require disclosure of non-commercial and nonfinancial information that is privileged or confidential, and the only support for that conclusion is the committee reports that were addressed to the earlier version of the bill, the version that was not enacted.

I cannot help but wish that the Attorney General's conclusion were a sound one, for $I$ think that all privileged or confidential information should be exempt from required disclosure, not merely such information which is commercial or financial. But the words "commercial or financial" were added to the statute, and I do not see how they can be interpreted to include non-commercial and non-financial information. I do not mean that statutory words should override a discernible congressional intent. On the contrary, my opinion is that intent is the fundamental; when intent can be discerned it should often override the statutory words, even when those words on their face seem reasonably clear. But the problem here is to determine what the intent was.

non-financial information, appears in the House committee's report: "[A] citizen must be able to confide in his Government. Moreover, where the Government has obligated itself in good faith not to disclose documents or information which it receives, it should be able to honor such obligations." Congress should have said this in the statute, but instead of saying it, Congress limited the fourth exemption to "commercial or financial information."

77 SEN. REP. 9. The only changes were addition of "lender-borrower" to the list of privileges and addition of a sentence that the exemption would cover "commercial, technical, and financial data, submitted by an applicant or a borrower to a lending agency in connection with any loan application or loan." The Attorney General's. Memorandum at page 33 argues that these changes expand the exemption, but I think not; addition of "lender-borrower" merely makes the exemption slightly more specific. The word "other" in the earlier report was already as broad as "lender-borrower."

78 House REP. 10.

79 Both the 1964 and the 1966 reports say, for example: "This exception is necessary to protect the confidentiality of information which is obtained by the Government through questionnaires or other inquiries, but which would customarily not be released to the public by the person from whom it was obtained." (Italics added.) That language is obviously addressed to the 1964 bill, which did not include the words "commercial or financial." The report twice uses the word "customarily" even though it had been deleted from the bill. 
Committee reports not addressed to the enacted version of the bill do not show the intent of Congress in enacting the statute. They show what the intent of Congress would have been if it had enacted the bill it did not enact.

The clear words of the statute are a better guide to legislative intent than committee reports that take no account of the enacted words.

The Attorney General's discussion of the fourth exemption involves an additional infirmity. It fails to take into account the provision of subsection (f) that availability of records cannot be limited "except as specifically stated." The Attorney General concludes that the fourth exemption protects from required disclosure "information given to the Government in confidence, whether or not involving commerce or finance."80 I do not see how any court could conscientiously find that an exemption of non-commercial and non-financial information is "specifically stated" by the statutory words "commercial or financial information obtained from any person and privileged or confidential."

The result that seems to me to be compelled by even the minimum degree of integrity in statutory interpretation is obviously unsatisfactory from a practical standpoint, because required disclosure of non-commercial and non-financial information which is privileged or confidential is clearly undesirable. The solution, in my opinion, should be in spite of the statute or outside the statute.

When the President signed the bill, he said that "this bill in no way impairs the President's power under our Constitution to provide for confidentiality when the national interest so requires." The President could build on that statement. He could announce that in the exercise of his power under the Constitution he finds that the national interest requires continued confidentiality for information submitted to the government with a good faith understanding that it is to be kept confidential, whether or not the information is commercial or financial. All officers of the executive branch could be so instructed. Then if judicial enforcement of the Act is sought, the court could avoid resort to the Constitution by explaining that the traditions of equity practice do not allow the court to compel an officer to violate a good faith understanding that information furnished to the government will be kept confidential.

Of course, the administration is now committed by the Attorney General's Memorandum to the view that the fourth exemption should be interpreted to reach non-commercial and non-financial information. That commitment means that all officers of the executive branch will withhold such information. That is enough to protect the information

80 ATt'Y GEN. MEMo. 34. 
but is it enough to avoid deterring private parties from continuing their normal practice of furnishing information to the government in confidence? If I were advising such a private party, I would feel more secure under a presidential finding of what the national interest requires than under what I consider to be an unsound analysis by the Attorney General.

\section{Privileged Information}

Even though the Attorney General's Memorandum does not inquire into the question of what information is privileged, such an inquiry seems desirable because (1) the statute exempts commercial or financial information which is privileged, (2) the statute may require disclosure of non-commercial and non-financial information which has heretofore been exempt from disclosure because of privilege, and (3) executive privilege, not mentioned by the Memorandum, may be of major consequence.

The committee reports mention three privileges that are usually unimportant to disclosure of government information but fail to mention privileges that are vital to that subject. Both reports say the fourth exemption "would include information customarily subject to the doctor-patient, lawyer-client, or lender-borrower privileges,"81 and the Senate Committee adds "and other such privileges." The physician-patient privilege is of no consequence here because the exemption is limited to commercial or financial information and because the sixth exemption, not so limited, covers "medical files." The lawyer-client privilege is of little consequence because the government through its lawyers seldom serves private clients. ${ }^{82}$ The lender-borrower privilege is usually of little consequence because commercial or financial information the borrower gives the government lender or guarantor in confidence is clearly exempt as confidential information.

Much the most important privilege about government records is executive privilege. The Act's word "privileged" can hardly be interpreted to exclude what is "privileged" under the doctrine of executive privilege, even though the committees failed to mention it.

A truly major proposition is this: Since the Act exempts "privileged" information which is commercial or financial and obtained from any person, since "privileged" information includes what is within executive privilege, and since the statute says nothing to deny assertions

81 SEN. REP. 9; House REP. 10.

82 The government has a lawyer-client relation with a private party when its lawyers serve as advisers to federal employees or others, represent a defendant in a court martial, or defend an officer who is sued in tort in his personal capacity on account of official action. 
by the executive branch that "the national interest" is the test of what is within executive privilege, the effect of the Act on disclosure of commercial or financial information obtained from any person is precisely zero, because executive privilege based on "the national interest" is still the test, as it was before the Act.

Congress did nothing to confine executive privilege as applied to commercial or financial information. In view of its basic purpose, the partial statutory adoption of executive privilege seems surprising. Congress could have-and in my opinion should have-limited the applicability of executive privilege. Although executive privilege as asserted by presidents is based upon the grant of executive power by article II of the Constitution, Congress has power to affect its meaning. To some unascertainable extent, the privilege is common law. In the Reynolds case, ${ }^{83}$ the Supreme Court spoke of " 'privileges' as that term is understood in the law of evidence," and of "the privilege against revealing military secrets, a privilege which is well established in the law of evidence." The Court cited an English case, and it made no mention of the Constitution. The flavor is that of common law.

Even to the extent that executive privilege is a constitutional doctrine, Congress has a great deal of practical power to provide a leadership in putting content into the doctrine.

The fourth exemption does indeed seem capricious with respect to privileges. Instead of carefully weighing each privilege and modifying it to accomplish the basic congressional purpose Congress takes two positions wholly incompatible with each other: (1) It abolishes all privileges with respect to non-commercial and non-financial information; (2) It preserves all privileges with respect to commercial or financial information, including especially executive privilege. I think it should have recognized the existence of executive privilege for all information and should have enacted some confinement of it. ${ }^{84}$

83 Reynolds v. United States, 345 U.S. 1, 6-7 (1953). The Court made no mention of the Constitution in holding that a secret contract for spying service should not be disclosed and therefore could not be enforced in the Court of Claims. Totten v. United States, 92 U.S. 105 (1875). See also the two excellent opinions Carl Zeiss Stiftung v. V.E.B. Carl Zeiss, Jena, 40 F.R.D. 318 (D.D.C. 1966); United States v. Tobin, 195 F. Supp. 588 (D.D.C. 1961), rev'd on other grounds, 306 F.2d 270, cert. denied, 371 U.S. 902 (1962).

84 The Act cuts across many other privileges in addition to executive privilege. Wigmore devotes eight hundred pages to privileges. 8 WIGMORE, EvideNcE 62-878 (McNaughton rev. 1961). An example is the informer privilege, which the Supreme Court has called "in reality the Government's privilege to withhold the identity of persons who furnish information of violations to officers." Roviaro v. United States, 353 U.S. 53, 59 (1957). Since the informer's identity is not "commercial or financial" information, it is not within the fourth exemption. It should be. Despite the flaws in the Act, I assume that officers and courts will respect the informer's privilege, by invoking executive privilege, by applying 


\section{Inter-Agency or Intra-Agency Memorandums or Letters}

The fifth exemption covers "inter-agency or intra-agency memorandums or letters which would not be available by law to a private party in litigation with the agency."

The APA defines "agency" to exclude Congress, a congressional committee, a congressman, a member of a staff of a congressman or committee, a court or judge, and state agencies and officers. Any communication between one of these and an agency is outside the exemption. For instance, confidential communications between the President and the governor of a state about plans for keeping racial peace in the state are clearly required to be disclosed..$^{85} \mathrm{But}$ an enforcing court, finding the Act irresponsible, might in an appropriate case invoke equity tradition or executive privilege.

One unintended result is both welcome and amusing. Congressmen increasingly help constituents in their dealings with bureaucrats. More than 200,000 complaints concerning administration reach congressional offices annually. ${ }^{86}$ Most of what congressmen do is innocuous and some of it is helpful, but some of it is harmful, especially when a congressman, with insufficient regard for the merits, puts pressure on an administrator for a favorable result. One careful student of the subject has asserted that "legislators, singly and collectively, are often the generators of rather than the guardians against maladministration." 87 Even though no one in Congress was aware that the Information Act would affect this problem, it provides a beautiful cure for the abuses by requiring correspondence between congressmen and agencies to be open to inspection. Probably notes recording a telephone conversation are not an intra-agency memorandum; an agency rule requiring such notes and providing for availability would be entirely appropriate. This is precisely what is needed-and no one planned it! If anyone's privilege is involved it is likely to be that of congressmen, and a claim of executive privilege would then be inappropriate.

equity traditions, or by using the seventh exemption for "investigatory files" even if the informer's identity is not in an investigatory file because no investigation has been made.

85 In my written statement to the Senate subcommittee I said: "If President Johnson and Governor Johnson of Mississippi exchange letters or telegrams about strategies for keeping racial peace in Mississippi, the papers will have to be made promptly available to any person, including those who want to defeat the strategies." See Hearings Before the Subcommittee on Administrative Practice and Procedure of the Senate Judiciary Committee on S. 1663, Administrative Procedure Act, 88th Cong., 2d Sess. 244, 248 (1964). With that observation before the subcommittee, it made no change. The President is forced to violate the statute, as I assume any President will, in the name of the constitutional doctrine of executive privilege.

86 Gellhorn, When Americans Complain 93 (1966).

87 Id. at 136. 
Both committee reports say that the purpose of the fifth exemption is to avoid inhibiting frank discussion in writing in the process of arriving at legal and policy positions. ${ }^{88}$ The exemption clearly serves that purpose, but the implication that the exemption does not go beyond that is unsound. It clearly reaches memorandums or letters which have nothing to do with the process of arriving at positions.

The explicit limit on the exemption is troublesome; it applies only to memorandums or letters which "would not be available by law to a private party in litigation with the agency." The words "a private party" seem to assume that every memorandum or letter would either be available or unavailable to "a private party" under discovery and related law, but that assumption is erroneous. All government records fall into three categories-those which are (1) always, (2) never, and (3) sometimes subject to discovery. The large category is probably the third, for the need of the party seeking the information is usually a factor. ${ }^{89}$ The fifth exemption is workable for the first and second categories. But when a memorandum or letter would be subject to discovery by a party whose need for it is strong but not by a party whose need for it is weak, should the agency disclose it, refuse disclosure, or apply discovery law to the facts about the particular applicant? The last course seems desirable, but the Act seems to forbid that course, for it requires disclosure to "any person" and it replaces the former statutory words "persons properly and directly concerned." 90 The applicant's need cannot be the test. The agency cannot say that one person is "any person" but that another person is not.

But since the purpose of the exemptions is to cut down the requirement of disclosure to "any person," the purpose of the fifth exemption could be to whittle down the "any person" requirement so that, in effect, only a person with a strong enough interest is entitled to disclosure of a memorandum or letter. This idea makes practical sense, but it is contrary to the words of the fifth exemption. The key words

88 The Senate committee said: "It was pointed out in the comments of many of the agencies that it would be impossible to have any frank discussion of legal or policy matters in writing if all such writings were to be subjected to public scrutiny. It was argued, and with merit, that efficiency of Government would be greatly hampered if, with respect to legal and policy matters, all Government agencies were prematurely forced to 'operate in a fishbowl." SEN REP. 9. The House committee made a similar statement. House REP. 10.

80 E.g., Hickman v. Taylor, 329 U.S. 495 (1947): "But the general policy against invading the privacy of an attorney's course of preparation is so well recognized and so essential to an orderly working of our system of legal procedure that a burden rests on the one who would invade that privacy to establish adequate reasons to justify production through a subpoena or court order." Id. at 512.

90 The Senate committee said the bill "eliminates the test of who shall have the right to different information." SEN. REP. 5. The House committee emphasized the same thought. HOUSE REP. 8. 
are "a private party." The words are not "the applicant" or "the party requesting disclosure." The focus is not on the applicant but on an abstract person, "a private party."

Then, if the Act cannot be interpreted to require an agency to disclose a memorandum or letter to one applicant and not another, the agency must choose between disclosing whenever any private party would be entitled to disclosure and withholding whenever any private party would not be entitled to disclosure. Neither the statute nor the Senate committee helps make this choice. But the House committee says that "any internal memorandums which would routinely be disclosed to a private party through discovery process in litigation would be available to the general public." 91 The key is that the disclosure is to "the general public" and not to the party requesting disclosure. The disclosure must be made to the public if "a private party"- not necessarily the applicant-would routinely be entitled to it through discovery.

So the applicant who is malevolent or merely curious has the same right to disclosure as the applicant who has a strong and legitimate need.

This result, in my opinion, is ( 1 ) undesirable because the discovery law as applied to the particular applicant would be a better test, but it is (2) based upon what seems to be a genuine intent of Congress and not merely on ineptitudes of the draftsmen.

The Attorney General's Memorandum discusses neither the disclosure of letters of congressmen nor the problem of whether "a private party" means the party who seeks records or some abstract party, but the Memorandum states a conclusion that

... internal communications which would not routinely be available to a party to litigation with the agency, such as internàl drafts, memoranda between officials or agencies, opinions and interpretations prepared by agency staff personnel or consultants for the use of the agency, and records of the deliberations of the agency or staff groups, remain exempt so that free exchange of ideas will not be inhibited. As the President stated upon signing the new law, "officials within Government must be able to communicate with one another fully and frankly without publicity."92

No one will quarrel with the President's statement, but one may wonder whether the Attorney General's statement goes beyond the

91 House REP. 10.

92 ATT'Y GEN. Memo. 35. 
President's and in doing so produces an unsound and undesirable result. The item I question is "opinions and interpretations prepared by agency staff personnel or consultants for the use of the agency." The Attorney General's Memorandum does not seem to take account of such possible facts as that the "opinions and interpretations" may constitute the working law of the agency, that the agency's employees may be instructed to apply such law in all individual cases, that the agency may be systematically withholding such law from affected parties, and that therefore the effect of non-disclosure may be to protect an outrageous system of secret law. Nor does the Attorney General's Memorandum refer at this point to the clear congressional intent that "interpretations" and "administrative staff manuals and instructions" must be disclosed, as subsection (b) specifically requires. The problem, unrecognized by the Memorandum, is the accommodation of the purpose behind the requirements of subsection (b) to the purpose behind the fifth exemption. I think such an accommodation calls for disclosure of all "opinions and interpretations" which embody the agency's effective law and policy, and the withholding of all papers which reflect the agency's group thinking in the process of working out its policy and determining what its law shall be. The need for secret communication among officials within the government should be recognized, but so should the need for prohibiting all secret law.

At another level on the same question, might "opinions and interpretations" be in the nature of an attorney's work product, so that they will be beyond the reach of discovery in litigation between a private party and the agency? I think the work product of a private attorney is something altogether different from a basic memorandum by the legal staff of an agency which is used by the agency as a guide in the handling of cases involving private parties. To the extent that such a memorandum states the effective law of the agency, its adoption by the agency makes it something more than the work product of the legal staff, even though the adoption appears in the agency's records only in such forms as "application granted" or "application denied."

The governing principle, which I think is without exception, is that secret law is forbidden.

\section{Personnel, Medical, and Similar Files}

The sixth exemption protects from required disclosure "matters that are ... personnel and medical files and similar files the disclosure of which would constitute a clearly unwarranted invasion of personal privacy." The draftsmanship this time is not seriously faulty, although I think the choice of the term "files" is unfortunate. 
The terms "personnel and medical files," "similar files," and "clearly unwarranted invasion of personal privacy" are all reasonably clear standards having meaning that can gradually be made more precise through case-to-case development. The statute requires an invasion of personal privacy and it even requires an unwarranted invasion of personal privacy so long as it is not "clearly unwarranted." The use of the word "clearly" is a legitimate expression of a policy judgment, although one may wonder about its wisdom.

The term "files" may cause trouble. It is a crude term that is inconsistent with meticulous discrimination. For instance, much information in medical files, such as an individual's presence at a hospital on a particular date, has nothing to do with privacy.

Even though the statute on its face exempts "files," common sense seems to me to call for disclosing some information within files and withholding other information, and the question whether the statute permits this is not easy. The natural assumption is that all three types of files-"personnel," "medical," and "similar"-must be treated alike in this respect. But the Attorney General's Memorandum surprisingly treats two in one way and the third in the other way by saying that what is exempt is

... all personnel and medical files, and all private or personal information contained in other files which, if disclosed to the public, would amount to a clearly unwarranted invasion of the privacy of any person ... ${ }^{93}$

The Memorandum gives no explanation for this differentiation, and I know of no explanation that can be given. ${ }^{94}$ I would treat all three in the same way.

Even though the statute and both committees speak of "files,"95 some evidence exists of an intent to allow picking and choosing within files, and policy considerations pull strongly in that direction. The Senate committee said that "facts concerning the award of a pension or benefit should be disclosed to the public,"96 and the House committee said the exemption does not cover "the facts concerning the award of a pension or benefit." 97 Taking out such facts means selecting within

93 Id. at 36.

94 The only reason $I$ can find for not treating all three alike operates against the Attorney General's conclusion. The 1964 version said "similar matter," and that was later changed to "similar files." The Attorney General adopts precisely the view that Congress rejected by making the change.

95 SEN. REP. 9; HOUSE REP. 10.

96 SEN. REP. 9.

97 HOUSE REP. 10. 
files. I believe that should be allowed with respect to all three kinds of files. Interpretation in this direction is not affected by the "specifically stated" clause.

The question whether whole files must be either closed or open suggests the further question whether whole documents must be either closed or open. What if a 65-page document is subject to required disclosure except for a few lines on page 33? The Act's words seem to discourage rather than to encourage a balancing of interests, but $I$ think that if the applicant for disclosure needs all but page 33 the practical answer is that this should be allowed. Similarly, just as a discovery order may reach facts in a document but not the legal analysis, other kinds of dividing of the contents of documents should be allowed when important interests will be served by it; the person inspecting part of a document will pay a fee to compensate for any inconvenience.

Although a corporation's privacy may deserve protection, I think a corporation cannot claim "personal privacy" within the meaning of the statutory terms. Again the Attorney General's Memorandum surprises me. Instead of using the statutory language of "personal privacy," the Attorney General speaks of "the privacy of any person" and then goes on to say that "person" is defined in section 2(b) of the APA to include corporations and other organizations but that the exemption "would normally involve the privacy of individuals rather than of business organizations." 98 I think "personal privacy" always relates to individuals. The definition of "person" seems to me irrelevant because the exemption does not use that term.

\section{Investigatory Files}

The seventh exemption from required disclosure covers "matters that are ... investigatory files compiled for law enforcement purposes except to the extent available by law to a private party."

The Senate committee says only: "These are the files prepared by Government agencies to prosecute law violators. Their disclosure of such files, except to the extent they are available by law to a private party, could harm the Government's case in court." 99 Although the term "law violators" could mean criminal law, that term is probably compatible with the House committee's interpretation: "This exemption covers investigatory files related to enforcement of all kinds of laws, labor and securities laws as well as criminal laws." 100 The House committee seems to me, however, to go beyond the terms of the statute

98 ATt'y GEN. MEMO. 36-37.

99 SEN. REP. 9.

100 House REP. 11. 
when it says: "This would include files prepared in connection with related Government litigation and adjudicative proceedings." Litigation files and adjudication files may include investigatory files compiled for law enforcement purposes but they may also include files that are not investigatory files compiled for law enforcement purposes. But perhaps this is what the House committee means, for it goes on to say that the bill "is not intended to give a private party indirectly any earlier or greater access to investigatory files than he would have directly in such litigation or proceedings." 101

The chief problem of interpreting this exemption will stem from the fact that investigations are often for multiple purposes, for purposes that change as the investigations proceed, and for purposes that are never clarified. Even the simplest question may be unanswerable in the statutory language: Is law enforcement the purpose of investigating the crash of a passenger plane? When the investigation begins no one may yet know. If the evidence disproves in three minutes a suspicion of bomb planting, but if three months are devoted to metal fatigue, is the file "compiled for law enforcement purposes"?

The Act is faulty in its use of the unsatisfactory term "files." Much of the contents of investigatory files compiled for purposes that may include law enforcement should not be exempt from required disclosure.

The committee reports shed no light on the meaning of the words "except to the extent available by law to a private party." Probably, for reasons explained above in our discussion of the fifth exemption, "a private party" means any party in the abstract and does not mean the particular party who is seeking the information. The law of the Jencks Act is applicable. ${ }^{102}$

\section{Regulating Financial Institutions}

The eighth exemption applies to "matters that are ... contained in or related to examination, operating, or condition reports prepared by, on behalf of, or for the use of any agency responsible for the regulation or supervision of financial institutions."

The Senate committee says this exemption "is directed specifically to insuring the security of our financial institutions by making available only to the Government agencies responsible for the regulation or supervision of such institutions the examination, operating, or condition reports prepared by, on behalf of, or for the use of such

101 Ibid.

10218 U.S.G. § 3500 (1964). 
agencies."103 We must be extremely careful or the facts about financial institutions might become known! We want the public to know the truth about almost all our institutions, but not about our financial institutions! At least, so says Congress, and what it says is the law. What it says is also in keeping with banking tradition, although that tradition rests heavily on facts of a former day such as uninsured bank accounts and runs on banks. The law is clear, but I still wish the lobbyists for the banking agencies had been less effective.

When an application is made to the Comptroller of the Currency for approval of a new national bank or a branch, an examiner interviews proponents and opponents, to dig up social, business, and economic facts, such as composition of the population, economic growth, banking needs, adequacy of the applicant's capital structure, and degree of public support. Such a report, until 1966, has always been "confidential." 104 I have proposed that such a report should be open, and apparently the Comptroller is now following that suggestion, although the regulation has not yet been formally changed. ${ }^{105} \mathrm{My}$ opinion is that Congress should not have provided that such a report is exempt from required disclosure. The other banking agencies are similarly maintaining systems of secret facts, secret law, and secret policy, and the eighth exemption will encourage such tendencies.

\section{Information about Wells}

The ninth and last exemption protects from required disclosure "matters that are ... geological and geophysical information and data (including maps) concerning wells." The Senate committee comments on all the exemptions but this one. The House committee explains that "witnesses testified that ... disclosure of the seismic reports and other exploratory findings of oil companies would give speculators an unfair advantage over the companies which spent millions of dollars in exploration." 106 I see no special problem of interpretation but $I$ am inclined to believe that the present regulation of the Bureau of Land Management is preferable to what Congress has enacted. Instead of exempting the records from required disclosure, the regulation makes them available unless their disclosure "would be prejudicial to the interests of the Government."107

\footnotetext{
103 SEN. REP. 10.

104 Comptroller's Guidelines for National Bank Directors $43-44$ (1964).

105 See Davis, Administrative Procedure in the Regulation of Banking, 32 LAw \& ConTEMr. Prob. 713 (1967).

106 HOUSE REP. 9.

10743 C.F.R. § 2.1 (1965).
} 


\section{Perspective and Conclusions}

Continuing our preliminary analysis, but shifting the focus from the separate provisions to the whole Act, let us now consider (1) the Act's accomplishments as to information, (2) its accomplishments as to secret law, (3) the weaknesses of enforcement, (4) problems of basic policy, (5) drafting deficiencies, (6) abuse of legislative history, (7) preclusion of judicial correction of legislative ineptitudes, and (8) amendments that are most needed and least controversial.

(1) The Act's accomplishments as to information. Probably more important than any other observations in all the foregoing discussion are three conclusions ${ }^{\mathbf{1 0 8}}$ about the fourth exemption (which protects from required disclosure "commercial or financial information obtained from any person and privileged or confidential"). The three conclusions are: (a) The Information Act is a nullity with respect to disclosure of commercial or financial information because when such information is "privileged" the Act exempts it from required disclosure, the word "privileged" probably includes what is within executive privilege, the test of executive privilege is "the national interest," and that was the test before the Act; (b) Because the fourth exemption is limited to commercial or financial information, the Act requires disclosure of non-commercial and non-financial information given to the government with the understanding that it will be kept confidential (unless it falls within another exemption, as much of it does not); such a result is so clearly unworkable that officers will refuse on the ground of executive privilege to make disclosures the Act requires and the courts will uphold the officers either on that ground or on the ground of equity traditions;"109 (c) Through the word "privileged," the Act with respect to commercial or financial information retains one hundred per cent of the previously existing law of privilege to the extent that that law protects against required disclosure, and at the same time the Act abolishes one hundred per cent of such law of privilege as applied to non-commercial and non-financial information; the abolition is so capricious that the law of privilege will survive its abolition, either because constitutional law of executive privilege will override the statute or because equity traditions will impel courts to refuse enforcement.

Because the first conclusion is that the law apart from the Act continues, and because the second and third conclusions are that the law apart from the Act overrides the Act whenever non-commercial and

108 See $\S \S 19,20$, and 21 supra.

109 See discussion of equity traditions in $\$ 6$ supra. 
non-financial information is privileged or confidential, combining the three conclusions produces this remarkable observation: The Act is a nullity with respect to all commercial or financial information, and with respect to all non-commercial and non-financial information which is privileged or confidential. The only information whose disclosure is governed by the Act's provisions, instead of by considerations beyond the Act, is non-commercial and non-financial information which is not privileged or confidential. This means that the Act governs disclosure of only a small portion of all government information.

To find what information is subject to required disclosure, we begin with that small portion and subtract what the Act exempts, the largest chunks being information about national defense or foreign policy within the first exemption, personnel and medical and similar files within the sixth, and investigatory files within the seventh. Not much is left. Even if we make the false assumption that the Act will be fully obeyed, ${ }^{110}$ the information the Act opens up that would otherwise be closed is minimal. The most important single category of information opened up may be those communications to and from agencies which are not otherwise exempt and which are not "inter-agency or intraagency memorandums or letters."

The overall conclusion is an easy one that the press, which was the principal political force behind the enactment, will benefit only slightly.

The conclusion that the Act is so unworkable that it must be in large measure superseded by official and judicial understanding based on considerations beyond the Act greatly increases the weight that must be given to the President's statement when he signed the bill that "this bill in no way impairs the President's power under our Constitution to provide for confidentiality when the national interest so requires." Anyone who doubts that statement in the abstract is likely to doubt it less as he realizes the extent of the need for escape from the Act's requirements.

If Congress had succeeded in enacting a workable system, the courts might have held that the statute defines the national interest or the public interest under the doctrine of executive privilege, and that the constitutional law and the common law of executive privilege are embodied in the statutory law, which then would become the foundation for all law of disclosure. But the courts cannot so hold, for they will often have to override the Act. Instead of building on the statute, the courts will build on three foundations-the statute, the public interest 
according to the doctrine of executive privilege, and equity traditions.

Just as the President's judgment about the national interest will determine what will be disclosed about national defense or foreign policy, the judgment of the executive branch about the national interest could control the release of all other information, despite the Act. But that is unlikely. The executive branch may be expected to find that the national interest usually coincides with the Act's provisions. The instances when it finds otherwise, however, are likely to be both frequent and important.

(2) The Act's accomplishments as to secret law. Although the bar played a minor role in getting the Act enacted, members of the bar and their clients will be the principal beneficiaries. Unlike the Act's accomplishments in opening up information, its accomplishments in opening up secret law are impressive. The most significant gains from the entire Act are those growing out of the requirement in subsection (b) of disclosure of six items-orders, opinions, statements of policy, interpretations, staff manuals, and instructions. An incidental gain is the opening of agency members' votes in proceedings, required by subsection (d). Although the exemptions of subsection (e) drastically affect the disclosure of information, their effect on disclosure of legal materials is relatively small.

The agencies could conceivably claim executive privilege with respect to some of the legal materials, but I think they are unlikely to do so, and I think the courts in general will enforce subsection (b) without modifying it either by executive privilege or by equity traditions, because subsection (b) is rather reasonable as it stands, so that neither officers nor judges will find occasion to search for ways to escape from it. The one exception is the requirement that all orders be indexed, but agencies may find feasible ways to comply with that requirement and the Information Act does not authorize courts to enforce it. Except for the indexing of all orders, no provision of subsection (b) seems to overreach; the deficiencies involve requiring too little, not requiring too much.

One unplanned benefit from the Information Act may be opening to public inspection communications between congressmen and administrative officers; improper pressures leading to denial of equal protection will be less common if the pressures can no longer be applied secretly.

(3) The weaknesses of enforcement. One distinct gain from the Act is its provision for judicial enforcement. The Act's words are entirely clear that the judicial enforcement provisions apply not only to subsection (c) but also to subsection (b), although some doubt exists as to 
whether that was the intent. ${ }^{111}$ Judicial enforcement of the provisions opening up secret law is as necessary and desirable as judicial enforcement of the provisions opening up secret facts.

Even with respect to what is judicially enforceable, we must not assume, in appraising what the Act accomplishes, that the Act will be carried out according to its terms, or even that the Act as modified by executive privilege and equity traditions will be fully enforced. Administrative violations will be widespread, and most of them will go uncorrected. Not the statute but the House committee's remarks in the direction of nondisclosure, reiterated by the Attorney General's Memorandum, will be the guide for most officers until a high court holds otherwise and in many instances until such a court so holds on the particular point with respect to the particular agency. In many vast fields of administration no case will be brought to compel disclosure, and the officers will know that such a case is unlikely.

One way to estimate probable violations is through a quick look backwards. The old APA required disclosure of records "except information held confidential for good cause found."112 The Attorney General formally provided in a regulation published in the Federal Register: "All files, documents, records and reports in the offices of the Immigration and Naturalization Service are regarded as confidential." 113 Simultaneously another subordinate of the Attorney General, the Board of Immigration Appeals, allowed all records of the same cases at the level of the Board to be open to public inspection. ${ }^{114}$ At neither level was any judgment made as to what information should be confidential "for good cause found." At one level facts having nothing to do with privacy or confidentiality were withheld, and at the other level clearly unwarranted invasions of personal privacy were freely allowed. When even the Attorney General, the principal law enforcer, sets such an example, many other agencies will have little concern for the abstract provisions in the statutes. ${ }^{115}$ And the reality

111 See $\S 10$ supra.

112 APA \& 3(c).

11319 Fed. Reg. 8071, \& 1.70 (1954).

114 The Board has advised me that all its records are open to public inspection and that all its proceedings are open to the public.

115 Sustained violations of this kind are not as uncommon as one might suppose. The United States Parole Board, another branch of the Department of Justice, has never complied with $\S 6$ (d) of the APA, requiring reasons for denying written applications. When a prisoner has waited for years to become eligible and is denied parole, he asks why. The Board tells him it never gives reasons. Yet the Board pretends to "rehabilitate" prisoners. The chairman has told me the APA does not apply. $I$ wish it were possible for him, inside the Department of Justice, to get some legal advice on that question. 
may be that fewer than one per cent of parties who want information and are entitled to it will go to court to get it.

As of this writing, only one set of proposed rules under the Information Act has come to my attention-those of the Immigration and Naturalization Service. ${ }^{116}$ By defining "opinion and order" to exclude all orders except those "accompanied by a statement of reasons," the proposed rules require nondisclosure of all other orders. Yet the Act is entirely clear in requiring disclosure of "all orders." I know of no reasonable argument that can be made in defense of the proposed rules in this respect. Perhaps this is a sample of what the agencies will do. If the proposed rules become final, who will be likely to go to court to require the Immigration Service to comply with the Information Act?

I recommend this additional means of enforcement: When an officer who has flagrantly violated the Act comes before a Senate committee for confirmation of an appointment, Senators should question him about his violations. A few such cases may have a magic effect.

(4) Problems of basic policy. A vital policy choice was to limit the Act to (a) requiring and (b) not requiring disclosures to the public. ${ }^{117}$ The Act never takes into account the need of the party seeking the disclosure; it never calls for balancing that need against the interest of a party adversely affected by disclosure. This policy choice reflects pressure from the press that "the public as a whole has a right to know"118 and does not reflect a thoughtful rejection of the balancing approach that has been a part of all judge-made law. When the time comes for further legislation, I think this policy choice might well be re-examined.

The Act never forbids disclosure. It never protects privileged or confidential information from disclosure; it protects only from required disclosure. No general federal statute prohibits clearly unwarranted invasions of personal privacy. Comprehensive legislation about disclosure would deal with required disclosures to the public, forbidden disclosures to the public, required disclosures to parties with special interests, and forbidden disclosures to individual parties as distinguished from disclosures to the public.

I am unconvinced that "the internal personnel rules and practices of

11632 Fed. Reg. 6781, 6787 (1967). Provision is made for disclosure of "unpublished decisions," but "decision" is defined to mean the same as "opinion and order," which is defined to include only "a final determination in a proceeding under the Act, accompanied by a statement of reasons," and to exclude explicitly "orders made by check marks, stamps, or brief endorsements which are not supported by a reasoned explanation, or opinion and orders incorporating preprinted language on Service forms."

117 See $\$ 4$ supra.

118 SEN. REP. 5. 
any agency" should be exempt from required disclosure. Some personnel information, such as appraisals by superiors of subordinates, should be protected, but I think the public should be entitled to know the "rules and practices."119

The exemption of "files" by the sixth and seventh exemptions is too broad; specified information should be exempt, not "files." Much that is contained in the exempt "files" should be disclosed.120

The eighth and ninth exemptions, about financial institutions and wells, respectively, are both broader than is necessary to accomplish their purposes. ${ }^{121}$

Indexing all orders seems to have been intended by Congress, despite the House committee's contradiction of the statute, and I think the requirement of such indexing was ill-advised, even though the agencies may find economical ways to comply with the requirement. ${ }^{122}$ The required indexing should be limited to opinions, statements of policy, interpretations, staff manuals, and instructions. These documents are a hundred times as useful as orders, and orders are a hundred times as numerous.

(5) Drafting deficiencies. That the Congress of the United States, after more than ten years of hearings, questionnaires, studies, reports, drafts, and pulling and hauling, should wind up with such a shabby product seems discouraging. The drafting deficiencies cannot be explained away as the product of extreme complexity, intractable subject matter, or unruly struggles between irreconcilable political philosophies. The failures in this instance are in the nature of inattention and indifference.

The House committee beautifully expressed a vital thought: “. . . a citizen must be able to confide in his Government. Moreover, where the Government has obligated itself in good faith not to disclose documents or information which it receives, it should be able to honor such obligations."123 But the bill as enacted, instead of expressing this thought, partly contradicts it. The statute clearly requires disclosure of non-commercial or non-financial information which is in good faith given to the Government in confidence. ${ }^{124}$ Such a result is so obviously unreasonable that a court might well judicially legislate that Congress meant the opposite of what its words say, but that seems to be prohibited by the provision of subsection (f) that information may not be

119 See $\$ 17$ supra.

120 See $\$ \$ 22$ \& 23 supra.

121 See $\$ \S 24$ \& 25 supra.

122 See \$ 14 supra.

123 HOUSE REP. 10.

124 See § 19 supra. 
withheld "except as specifically stated" in the statute. Congress has not only legislated badly but has taken pains to prevent the courts from correcting its ineptitudes.

Other drafting deficiencies throughout the Act are almost as serious. The Act authorizes deletion of identifying details in disclosing documents "to the extent required to prevent a clearly unwarranted invasion of personal privacy," but it does not authorize deletion to protect information received in confidence. ${ }^{125}$ The word "all" appearing before two of the six items in subsection (b) but not before any of the others seems to be the result of carelessness. ${ }^{126}$ The exemption in (e)(5) of what "would not be available by law to a private party in litigation with the agency" is based on the erroneous assumption that what is available to "a private party" is the same as what is available to another private party; an inquiry into the law of discovery would have corrected this error. ${ }^{127}$

The introductory words of subsection (c), "Except with respect to the records made available pursuant to subsections (a) and (b)," are nonsense and may have been intended to be: "Except with respect to the records not made available as required by subsections (a) and (b)."

Failures such as these may be one reason why some political scientists are pointing out that, along with other legislative bodies throughout the world, Congress has declined drastically in both power and prestige. "No longer is Congress the source of major legislation." ${ }^{128}$ Congress has lost most of the power it once had to initiate and to plan legislation. Eighty per cent of current legislation originates in the executive branch. ${ }^{129}$ No longer is Congress the principal legislative organ of the government; the executive is. Congress is, in the main, limiting itself to the role of approving, modifying, vetoing or partly vetoing legislation initiated and formulated by the executive.

Perhaps the deficiencies of the Information Act are a fair sample of congressional formulation of its own legislation, without the help of the executive. Who is responsible for the deficiencies? The answer is the 535 men and their staffs, primarily the subcommittees and their staffs. But the responsibility probably cannot be further pinpointed. Among individuals it is widely diffused. The diffusion is splendidly geared to policy choices when many interests are pulling in all directions. But the system fails to assure reliable judgments about nonpolitical complexities. Congressmen are neither penalized nor rewarded

125 See $\$ 13$ supra.

126 See note 55 supra.

127 See $\$ 21$ supra.

128 Huntington, Congressional Responses to the Twentieth Century, in The Congress AND AMERICA's Future 5, 22 (Truman ed. 1965).

129 Ibid. 
for indifference or excellence in doing the thinking that goes with drafting, and the staffs largely reflect the same motivations or lack of them. Both the congressmen and the staffs include able and dedicated individuals, but the system still tends to miscarry in absence of the kind of assistance that executive officials usually supply.

What seems to me lacking is the designation of a single top-level individual for each piece of legislation which becomes final, who has the responsibility, the capacity, and the incentive to perform the backstop job of protecting against serious inadvertences and oversights. I would not expect this from a subcommittee chairman; his attention should be primarily elsewhere. The individual should be a staff member, not a congressman. The authors of the Attorney General's Memorandum show insights that were largely lacking in the legislative process; I often quarrel with their positions as advocates but I respect their mastery of the complexities. Congress needs assistants of that caliber. Committee counsel are supposed to do the technical job, but their responsibility is diluted in two ways: Many others share it, and they have many other tasks. Perhaps what is needed is a stronger focusing in one individual of final responsibility for technical competence.

6. Abuse of the legislative history. After the bill had passed the Senate on the basis of a committee report that was reasonably faithful to the words of the bill, the House committee was subjected to pressures to restrict the disclosure requirements. It yielded to the pressures. But it did not change the bill. Instead, it wrote the restrictions into the committee report. These restrictions differ drastically from the bill as passed by the Senate; they often contradict the words of the bill, ${ }^{130}$ and they sometimes contradict both the statutory words and the Senate committee report. ${ }^{131}$

I believe (a) that statements in a House committee report that contra-

130 Many examples of the House committee's contradiction of clear statutory language are presented in the foregoing pages. Perhaps the best example is the statutory requirement that "all orders" and "all opinions" be made available and its requirement of an index of "any matter ... required by this subsection to be made available." The statute seems to me entirely clear in requiring all orders and all opinions to be indexed. The Senate committee discussed the requirement in the bill's language, saying nothing at variance with that language. SEN. REP. 7. The House committee said "documents having precedential significance" must be indexed, thus excluding from the index requirement more than ninety per cent of the documents required to be made available. HOUSE REP. 8.

131 The best example of such a contradiction may be the exemption of "internal personnel rules," which obviously has to do with such items as employees' parking facilities, lunch hours, and sick leave, as the Senate committee quite properly explained. SEN. REP. 8. The House committee said this exemption reaches "operating rules, guidelines, and manuals of procedure for Government investigators or examiners." HouSE REP. 10. This seems to me a contradiction of both the statute and the Senate committee report, for rules governing relations between agency employees and outsiders are not "internal personnel rules." 
dict the bill and depart from the understanding of the Senate committee are not the law, and (b) that inserting such statements into a committee report, instead of changing the bill, is a clear abuse. I realize that habits have grown up in some quarters, both legislative and judicial, that are sometimes at variance with these two beliefs, but such habits seem to me very much in need of re-examination. The basic principle is quite elementary: The content of the law must depend upon the intent of both Houses, not of just one. In this instance, only the bill, not the House committee's statements at variance with the bill, reflects the intent of both Houses. Indeed, no one will ever know whether the Senate committee or the Senate would have concurred in the restrictions written into the House committee report.

All along the line, I think the Attorney General's Memorandum is unsound in assuming that whatever the House committee says is the law even when the words of the statute are unequivocally the opposite. The agencies, of course, will follow the Memorandum because it strains in the direction they want to go. But the courts will provide a better balance.

The reasons why the courts will reject the House committee's abuse of legislative history, even though the Attorney General supports it, are overwhelming. Allowing the meaning of clear statutory words to be drastically changed by the House committee report would have many unsound consequences. Three major ones are: (1) The House that acts first would be deprived of any voice in the final meaning of the enactment, for the House that acts second could always adopt the same bill but alter its meaning through committee reports. (2) The sound system of the conference committee would be defeated, for the House that acts second, even when it knows the other House disagrees, could always make law as it chooses through the committee reports. (3) Statutes which are clear on their face would become unreliable indicia of the effective law. Indeed, if the Attorney General's Memorandum were to prevail, no careful lawyer could ever give advice by looking at a statute; he would always have to examine the legislative history.

Those who sponsor committee contradictions of statutory language should change the bill if they have the power to do so. If they lack that power, their view should not be written into committee reports. The occasional tendency of some courts to rely on committee contradictions of bills should be checked. Very helpful would be more judicial opinions stating that language in a committee report which is at variance with language in a bill tends to show that the sponsors of the committee language were unsuccessful in their effort to put that language into the bill. 
(7) Preclusion of judicial contributions. The courts have much to contribute to the difficult process of producing workable and sensible legislation, as much experience proves. Limited imagination, oversights, inadvertences, and imprecise expression can be and often are eased or corrected by sympathetic interpretation which emphasizes basic legislative purposes. Mr. Justice Frankfurter acknowledged the need for "imaginative interpretation." 132 Judge Learned Hand asserted that "one of the surest indexes of a mature and developed jurisprudence is not to make a fortress of the dictionary, but to remember that statutes always have some purpose to accomplish, whose sympathetic and imaginative discovery is the surest guide to their meaning." 133 Yet subsection (f) provides that information may not be withheld "except as specifically stated" in the statute. ${ }^{134}$ This seems to me to say with force and clarity that the courts are barred from "imaginative interpretation" of the exemptions and that they must "make a fortress of the dictionary."

Even when drafting reaches an unusually high level of competence, preventing the courts from constituting themselves working partners with the legislative body to produce satisfactory law would be clearly undesirable. When the drafting is as slipshod as that of the Information Act, a "specifically stated" clause that deters correction of legislative errors in one direction, no matter who is hurt or how much, seems especially unfortunate.

I think the "specifically stated" clause ought to be repealed.

(8) Amendments most needed and least controversial. We can live with the Act because of the two fortunate facts, neither of which stems from Congress, that executive privilege ${ }^{135}$ can override the Act and that equity traditions ${ }^{136}$ can impel a court to refuse enforcement. Yet I think a dozen or more amendments are needed, as the foregoing discussion shows. Even so, I shall here merely give emphasis to the four amendments that seem most needed and least likely to invite controversy.

(a) The fourth exemption is most urgently in need of amendment. It exempts from disclosure "trade secrets and commercial or financial information obtained from any person and privileged or confidential." The Act contains no exemption for privileged or confidential information which is non-commercial and non-financial. ${ }^{137}$ The fourth exemp-

132 FCC v. RCA Communications, 346 U.S. 86,90 (1953).

133 Cabell v. Markham, 148 F.2d 737, 739 (2d Cir. 1945).

134 See § 15 supra.

135 See $\$ 3$ supra.

136 See \& 6 supra.

137 See § 19 supra. 
tion should be amended to read: "trade secrets and privileged or confidential information obtained from any person."

(b) Subsection ( $f$ ) provides: "Nothing in this section authorizes withholding of information or limiting the availability of records to the public except as specifically stated in this section ...." The word "provided" should be substituted for the words "specifically stated" so that the courts will have their normal elbow room to make their own very much needed contributions to a workable and sensible system. ${ }^{138}$

(c) The first sentence of subsection (b) should be amended to make clear that statements of policy and interpretations adopted by an authorized representative of the agency are included, to make clear that statements of policy and interpretations must be disclosed whether or not they are used as precedents and whether or not they are the end products of administration, and to make clear that manuals and instructions must be disclosed to the extent that they embody the law of the agency. ${ }^{139}$ The sentence should be amended to read: "Every agency shall, in accordance with published rules, make available for public inspection and copying (A) final opinions (including concurring and dissenting opinions) and orders made in the adjudication of cases, (B) statements of policy and interpretations which have been adopted by the agency or by any authorized representative of the agency, whether or not the statements or interpretations are used as precedents and whether or not they are the end products of administration, and (C) administrative staff manuals and instructions to staff that affect any member of the public, to the extent that the manuals or instructions embody the law of the agency."

(d) The second sentence of subsection (b) authorizes deletion of identifying details "to the extent required to prevent a clearly unwarranted invasion of personal privacy." It should also authorize such deletion to protect confidential information or to prevent other special harm. ${ }^{140}$ Part of the sentence should be amended to read: "To the extent required to prevent harm to any person from the disclosure of information, an agency may delete identifying details when it makes available or publishes an opinion, statement of policy, staff manual, or instruction."

138 See $\$ 15$ supra.

139 See $\$ \S 9,11$, and 12 supra.

140 See $\$ 13$ supra. 


\section{APPENDIX}

\section{Section 3 of the Administrative Procedure Act as amended by 80 Stat. 250 (1966).}

SEc. 3. Every agency shall make available to the public the following information:

(a) Publication in the Federal Register.-Every agency shall separately state and currently publish in the Federal Register for the guidance of the public (A) descriptions of its central and field organization and the established places at which, the officers from whom, and the methods whereby, the public may secure information, make submittals or requests, or obtain decisions; (B) statements of the general course and method by which its functions are channeled and determined, including the nature and requirements of all formal and informal procedures available; (C) rules of procedure, descriptions of forms available or the places at which forms may be obtained, and instructions as to the scope and contents of all papers, reports, or examinations; (D) substantive rules of general applicability adopted as authorized by law, and statements of general policy or interpretations of general applicability formulated and adopted by the agency; and (E) every amendment, revision, or repeal of the foregoing. Except to the extent that a person has actual and timely notice of the terms thereof, no person shall in any manner be required to resort to, or be adversely affected by any matter required to be published in the Federal Register and not so published. For purposes of this subsection, matter which is reasonably available to the class of persons affected thereby shall be deemed published in the Federal Register when incorporated by reference therein with the approval of the Director of the Federal Register.

(b) AGENCY OPINIONS AND ORDERs.-Every agency shall, in accordance with published rules, make available for public inspection and copying (A) all final opinions (including concurring and dissenting opinions) and all orders made in the adjudication of cases, (B) those statements of policy and interpretations which have been adopted by the agency and are not published in the Federal Register, and (C) administrative staff manuals and instructions to staff that affect any member of the public, unless such materials are promptly published and copies offered for sale. To the extent required to prevent a clearly unwarranted invasion of personal privacy, an agency may delete identifying details when it makes available or publishes an opinion, statement of policy, interpretation, or staff manual or instruction: Provided, That in every case the justification for the deletion must be fully explained in writing. Every agency also shall maintain and make available for public inspection and copying a current index providing identifying information for the public as to any matter which is issued, adopted, or promulgated after the effective date of this Act and which is required by this subsection to be made available or published. No final order, opinion, statement of policy, interpretation, or staff manual or instruction that affects any member of the public may be relied upon, used or cited as precedent by an agency against any private party unless it has been indexed and either made available or published as provided by this subsection or unless that private party shall have actual and timely notice of the terms thereof.

(c) AGENCY RECORDs-Except with respect to the records made available pursuant to subsections (a) and (b), every agency shall, upon request for identifiable records made in accordance with published rules stating the time, place, fees to the extent authorized by statute and procedure to be followed, make such records promptly available to any person. Upon complaint, the district court of the United States in the district in which the complainant resides, or has his principal place of business, or in which the agency records are situated shall have jurisdiction to enjoin the agency from the withholding of 
agency records and to order the production of any agency records improperly withheld from the complainant. In such cases the court shall determine the matter de novo and the burden shall be upon the agency to sustain its action. In the event of noncompliance with the court's order, the district court may punish the responsible officers for contempt. Except as to those causes which the court deems of greater importance, proceedings before the district court as authorized by this subsection shall take precedence on the docket over all other causes and shall be assigned for hearing and trial at the earliest practicable date and expedited in every way.

(d) Agency Proceedings.-Every agency having more than one member shall keep a record of the final votes of each member in every agency proceeding and such record shall be available for public inspection.

(e) EXEMPTIONs.-The provisions of this section shall not be applicable to matters that are (1) specifically required by Executive order to be kept secret in the interest of the national defense or foreign policy; (2) related solely to the internal personnel rules and practices of any agency; (3) specifically exempted from disclosure by statute; (4) trade secrets and commercial or financial information obtained from any person and privileged or confidential; (5) inter-agency or intra-agency memorandums or letters which would not be available by law to a private party in litigation with the agency; (6) personnel and medical files and similar files the disclosure of which would constitute a clearly unwarranted invasion of personal privacy; (7) investigatory files compiled for law enforcement purposes except to the extent available by law to a private party; (8) contained in or related to examination, operating, or condition reports prepared by, on behalf of, or for the use of any agency responsible for the regulation or supervision of financial institutions; and (9) geological and geophysical information and data (including maps) concerning wells.

(f) Limitation of Exemprions.-Nothing in this section authorizes withholding of information or limiting the availability of records to the public except as specifically stated in this section, nor shall this section be authority to withhold information from Congress.

(g) Private Party.-As used in this section "private party" means any party other than an agency.

(h) Effective Date.-This amendment shall become effective one year following the date of the enactment of this Act.

\section{U.S.C. $\S 552$ as amended by 81 Stat. 54 (1967).}

§ 552. Public information; agency rules, opinions, orders, records, and proceedings

(a) Each agency shall make available to the public information as follows:

(1) Each agency shall separately state and currently publish in the Federal Register for the guidance of the public-

(A) descriptions of its central and field organization and the established places at which, the employees (and in the case of a uniformed service, the members) from whom, and the methods whereby, the public may obtain information, make submittals or requests, or obtain decisions;

(B) statements of the general course and method by which its functions are channeled and determined, including the nature and requirements of all formal and informal procedures available;

(C) rules of procedures, descriptions of forms available or the places at which forms 
may be obtained, and instructions as to the scope and contents of all papers, reports, or examinations;

(D) substantive rule of general applicability adopted as authorized by law, and statements of general policy or interpretations of general applicability formulated and adopted by the agency; and

(E) each amendment, revision, or repeal of the foregoing.

Except to the extent that a person has actual and timely notice of the terms thereof, a person may not in any manner be required to resort to, or be adversely affected by, a matter required to be published in the Federal Register and not so published. For the purpose of this paragraph, matter reasonably available to the class of persons affected thereby is deemed published in the Federal Register when incorporated by reference therein with the approval of the Director of the Federal Register.

(2) Each agency, in accordance with published rules, shall make available for public inspection and copying-

(A) final opinions, including concurring and dissenting opinions, as well as orders, made in the adjudication of cases;

(B) those statements of policy and interpretations which have been adopted by the agency and are not published in the Federal Register; and

(C) administrative staff manuals and instructions to staff that affect a member of the public;

unless the materials are promptly published and copies offered for sale. To the extent required to prevent a clearly unwarranted invasion of personal privacy, an agency may delete identifying details when it makes available or publishes an opinion, statement of policy, interpretation, or staff manual or instruction. However, in each case the justification for the deletion shall be explained fully in writing. Each agency also shall maintain and make available for public inspection and copying a current index providing identifying information for the public as to any matter issued, adopted, or promulgated after July 4,1967 , and required by this paragraph to be made available or published. A final order, opinion, statement of policy, interpretation, or staff manual or instruction that affects a member of the public may be relied on, used, or cited as precedent by an agency against a party other than an agency only if-

(i) it has been indexed and either made available or published as provided by this paragraph; or

(ii) the party has actual and timely notice of the terms thereof.

(3) Except with respect to the records made available under paragraphs (1) and (2) of this subsection, each agency, on request for identifiable records made in accordance with published rules stating the time, place, fees to the extent authorized by statute, and procedure to be followed, shall make the records promptly available to any person. On complaint, the district court of the United States in the district in which the complainant resides, or has his principal place of business, or in which the agency records are situated, has jurisdiction to enjoin the agency from withholding agency records and to order the production of any agency records improperly withheld from the complainant. In such a case the court shall determine the matter de novo and the burden is on the agency to sustain its action. In the event of noncompliance with the order of the court, the district court may punish for contempt the responsible employee, and in the case of a uniformed service, the responsible member. Except as to causes the court considers of greater importance, proceedings before the district court, as authorized by this paragraph, take precedence on the docket over all other causes and shall be assigned for hearing and trial at the earliest practicable date and expedited in every way.

(4) Each agency having more than one member shall maintain and make available for public inspection a record of the final votes of each member in every agency proceeding.

(b) This section does not apply to matters that are-

(1) specifically required by Executive order to be kept secret in the interest of the national defense or foreign policy; 
(2) related solely to the internal personnel rules and practices of an agency;

(3) specifically exempted from disclosure by statute;

(4) trade secrets and commercial or financial information obtained from a person and privileged or confidential;

(5) inter-agency or intra-agency memorandums or letters which would not be available by law to a party other than an agency in litigation with the agency;

(6) personnel and medical files and similar files the disclosure of which would constitute a clearly unwarranted invasion of personal privacy;

(7) investigatory files compiled for law enforcement purposes except to the extent available by law to a party other than an agency;

(8) contained in or related to examination, operating, or condition reports prepared by, on behalf of, or for the use of an agency responsible for the regulation or supervision of financial institutions; or

(9) geological and geophysical information and data, including maps, concerning wells.

(c) This section does not authorize withholding of information or limit the availability of records to the public, except as specifically stated in this section. This section is not authority to withhold information from Congress.

SEc. 2. The analysis of chapter 5 of title 5, United States Code, is amended by striking out:

"552. Publication of information, rules, opinions, orders, and public records." and inserting in place thereof:

"552. Public information; agency rules, opinions, orders, records, and proceedings."

SEC. 3. The Act of July 4, 1966 (Public Law 89-487, 80 Stat. 250), is repealed.

SEC. 4. This Act shall be effective July 4, 1967, or on the date of enactment, whichever is later. 